https://helda.helsinki.fi

\title{
The supercontinent cycle
}

\section{Mitchell, Ross}

2021-05

Mitchell , R , Zhnag , N , Salminen , J , Liu , Y, Spencer , C , Steinberger , B , Murphy , B \& Zheng-Xian , L 2021 , ' The supercontinent cycle ' , Nature Reviews Earth \& Environment , vol. 2 , no. 5 , pp. 358-374 . https://doi.org/10.1038/s43017-021-00160-0

http://hdl.handle.net/10138/335509

https://doi.org/10.1038/s43017-021-00160-0

acceptedVersion

Downloaded from Helda, University of Helsinki institutional repository.

This is an electronic reprint of the original article.

This reprint may differ from the original in pagination and typographic detail.

Please cite the original version. 


\title{
The supercontinent cycle
}

\author{
Ross N. Mitchell1t, Nan Zhang2t, Johanna Salminen 3 , Yebo Liu ${ }^{4}$, Christopher J. Spencer ${ }^{5}$, \\ Bernhard Steinberger ${ }^{6,7}$, J. Brendan Murphy ${ }^{8}$, Zheng-Xiang Lit
}

${ }^{1}$ State Key Laboratory of Lithospheric Evolution, Institute of Geology and Geophysics, Chinese Academy of Sciences, Beijing, China.

${ }^{2}$ Key Laboratory of Orogenic Belts and Crustal Evolution, Institution of Earth and Space Sciences, Peking University, Beijing, China.

${ }^{3}$ Deparment of Geosciences and Geography, University of Helsinki, Helsinki, Finland.

${ }^{4}$ Earth Dynamics Research Group, School of Earth and Planetary Sciences, Curtin University, Western Australia, Australia.

${ }^{5}$ Department of Geological Sciences and Geological Engineering, Queen's University, Kingston, Ontario, Canada.

${ }^{6}$ Section 2.5 Geodynamic Modelling, GFZ German Research Centre for Geosciences, Potsdam, Germany,

${ }^{7}$ Centre for Earth Evolution and Dynamics, University of Oslo, Oslo, Norway.

${ }^{8}$ Department of Earth Sciences, St. Francis Xavier University, Antigonish, Nova Scotia, Canada.

tEmails: ross.mitchell@mail.iggcas.ac.cn,nan_zhang@pku.edu.cn

Abstract | Supercontinents signify self-organization in plate tectonics. Over the past $\sim 2$ billion years 3 major supercontinents have been identified, with increasing age: Pangaea, Rodinia, and Columbia. In a prototypal form, a cyclic pattern of continental assembly and breakup likely extends back to $\sim 3$ billion years ago, albeit on the smaller scale of Archaean supercratons which, unlike global supercontinents, were tectonically segregated. In this Review, we discuss how the emergence of supercontinents provides a minimum age for the onset of the modern global plate tectonic network, whereas Archaean supercratons might reflect an earlier geodynamic and nascent tectonic regime. The assembly and breakup of Pangaea attests that the supercontinent cycle is intimately linked with whole mantle convection. The supercontinent cycle is interpreted both as an effect and a cause of mantle convection, emphasizing the importance of both top-down and bottom-up geodynamics and the coupling between them. However, the nature of this coupling and how it has evolved remains controversial, resulting in contrasting models of supercontinent formation which can be tested by quantitative geodynamic modeling and geochemical proxies. Specifically, which oceans close to create a supercontinent, and how such predictions are linked to mantle convection, are directions for future research.

TOC summary:

Repeated amalgamation and dispersal of continents over Earth history is known as the supercontinent cycle, however the geodynamic processes driving this cyclicity remain debated. This Review synthesizes observations, plate reconstructions, and geodynamic models of supercontinents and older Archaean supercratons.

[H1 ] Introduction

Supercontinents emerge as a result of the fact plate tectonics is a self-organizing complex system. Plate tectonics is a highly complex system that can be considered simply as a force 
balance between slab pull and ridge push (from the plates themselves) and basal drag (from the convecting mantle). However, such a description of the fundamental parts of the system does not provide an explanation how plate tectonics occurs as a consequence of mantle convection ${ }^{1,2}$. Plate tectonics is a prime example of self-organization or emergence in a system, which refers to the collective phenomena of a complex, evolving system not apparent in its parts ${ }^{3,4}$, and supercontinents emerge as a result of these collective, interrelated tectonic and convective processes. That is, understanding the forces of all plate boundaries globally but individually cannot account for supercontinent dynamics, whereas how these parts of the system interact as a wider whole can begin to explain why supercontinents assemble and breakup.

The supercontinent cycle plays a major role in how Earth's interior and surface both operate, interact, and evolve with each other ${ }^{5-10}$. Hence, supercontinent kinematics are a critical boundary condition for constraining the evolution of Earth's surface $5,6,11-14$. Advances in palaeogeographic reconstructions and geodynamic modelling have allowed these approaches to now be coupled, providing a clearer picture of the supercontinent cycle, with exciting implications for understanding how tectonics has co-evolved with major changes in Earth's surface environment over the past few billion years.

The existence of the supercontinent Pangaea was first evidenced by the fit of continents (namely, Africa and South America) which led to the hypothesis of continental driftAlfred Wegener's prototypical theory ${ }^{15}$ that later evolved into the theory of plate tectonics decades later ${ }^{16-22}$. Because plate tectonics has been operational for at least 2 billion years ${ }^{23-26}$ (Gyr), if not longer 27-30, the likelihood of the existence of pre-Pangaea supercontinents is high. At least three supercontinents have been identified, with increasing age: Pangaea, Rodinia, and Columbia (Fig. 1). It is thus now appropriate to use the term supercontinent cycle, as three recurrences are the bare minimum such that one can reasonably talk about cyclicity.

The operational definition of a supercontinent employed here includes several aspects, which are not mutually exclusive, including: large size; a mantle legacy; and longevity. A supercontinent does not necessarily have to include all continents - for example, even Pangaea did not include North and South China or other Cimmerian blocks (Fig. 1). The size criterion is typically considered either qualitatively to include most continents ${ }^{31}$, or quantitatively to meet a threshold of $75 \%$ of available continental crust at any given time $^{32}$. The second criterion (a mantle legacy) has been suggested to offer a more geodynamically meaningful solution, for example, a supercontinent must have been large enough to have been associated with long-wavelength mantle convection ${ }^{33}$. Another aspect of such a mantle legacy, however, is longevity, as a supercontinent must have existed for a sufficient amount of time (at least $\sim 100$ million years) for the affect on mantle flow to take effect.

Each supercontinent cycle has two main phases, assembly and breakup. It is, however, a common misconception to think of the supercontinent cycle as a binary process (that is, supercontinent or no supercontinent) because the assembly and breakup phases can temporally overlap. For example, the East African rift ${ }^{34}$ (continued breakup of Pangaea) and the continental collision of India with Eurasia ${ }^{35}$ (assembly of the next supercontinent) both occur simultaneously in Cenozoic time. A supercontinent cycle is often considered to last 400-800 million years ${ }^{36}$ (Myr), where a statistical basis for such 
a $\sim 600$ Myr duration has been identified using time series analysis of hafnium isotopes of zircon ${ }^{37}$, a geochemical proxy for the supercontinent cycle ${ }^{38}$. To be clear, the stable tenure period of a supercontinent (after assembly and before breakup) represents only a small duration of this full cycle, where tenures of the past known supercontinents have lasted between 100 and $300 \mathrm{Myr}^{39}$ (Fig. 1).

In this Review, we describe the supercontinent cycle throughout Earth history. The geological evidence for the historical record of supercontinents is appraised, and the insights from geodynamic modeling as a potential explanation for the dynamics of supercontinent assembly and breakup are explored. From these discussions, we suggest that supercontinent cycles can be explained within a theory that connects plate tectonics and mantle dynamics. Finally, after identifying areas of continued uncertainty, future research directions that are required to develop a more robust model of supercontinent formation that is consistent with both data and theory are outlined.

\section{[H2] The supercontinent cycles}

In this section, we discuss the evidence for historical supercontinents throughout Earth history, by exploring the geologic, tectonic, and geophysical evidence that informs the geodynamics of each known supercontinent, and commonalities and differences among them. We also discuss how numeral modeling of mantle convection relates to such supercontinent dynamics. Finally, ancient Archaean time is surveyed for which there is not yet a compelling case for a supercontinent and the reasons for why it might not be plausible to expect one are discussed.

\section{[H2] Pangaea}

Pangaea was present from ca. 320 to $180 \mathrm{Ma}$ (Fig.1), and was the first supercontinent recognized by geologists. The history of Pangaea's existence and tectonic kinematics have been debated and refined for over a century ${ }^{15,40-50}$. As most of this history is well documented ${ }^{41,45}$, the focus here is on how the understanding of the most recent supercontinent informs the linkages between its tectonic evolution (assembly and breakup) and mantle convection, that is, its geodynamics. Established linkages between Pangaea and the underlying convecting mantle include: large igneous provinces (LIPs) [G] emplaced by mantle plumes [G] sourced from the edges of large low shear-wave velocity provinces (LLSVPs) [G] in the deep mantle ${ }^{51-57}$; net characteristics of plate motions during Pangaea tenure and breakup that reflect coupling with long-wavelength mantle convective patterns ${ }^{58-62}$; and repeated oscillatory true polar wander (TPW) [G] events whereby the spin axis approximately follows a great circle orthogonal to a stable axis controlled by supercontinent-reinforced long-wavelength mantle flow ${ }^{45,56,60,63-71}$.

Currently, divergent views on the evolution of mantle convection exist. On Earth today, mantle convection is dominated by large-wavelength cells ${ }^{72,73}$, yielding most power at harmonics degree 1 mantle flow [G] and degree 2 mantle flow [G] ${ }^{74}$. Recent plate motions associated with Pangaea and its breakup exhibit net characteristics that follow these longest wavelength patterns in mantle flow, although the relative dominance of degree 1 mantle flow versus degree 2 mantle flow might have fluctuated over time ${ }^{58}$. It has been speculated that mantle flow has always followed degree 2 structure in essentially its present form $51,53,54,56,75$, but it has also been argued that such longevity is unlikely beyond $300 \mathrm{Ma}$ and the structure seen today only relates to the most recent Pangaea supercontinent cycle ${ }^{76}$. 
Those workers considering dynamic and evolving mantle convection patterns have modelled potential changes in mantle flow farther back in time with proxy plate motion reconstructions and subduction histories ${ }^{73,77}$. For example, by constraining numerical models of mantle convection with plate reconstructions as an upper boundary condition, some have argued that the Palaeozoic (before $300 \mathrm{Ma}$ ) was characterized by the dominance of degree 1 flow during the assembly of Pangaea ${ }^{73}$. Orthoversion [G] theory ${ }^{60}$ hypothesizes that each supercontinent cycle shifts the longitude of degree 2 flow orthogonally $\left(\sim 90^{\circ}\right)$, such that the degree 2 flow planforms of each supercontinent cycle can be spatially linked and palaeolongitude can thus be constrained. Orthoversion thus stipulates that Pangaea formed $\sim 90^{\circ}$ away from its predecessor, which is supported by palaeomagnetic data interpreted to constrain palaeolongitude ${ }^{60}$.

The palaeogeography of supercontinent Pangaea at the age 20 Myr before breakup (ca. $200 \mathrm{Ma}$ ) is thought to be linked to the shape of present-day mantle structures based on their close spatial association 45,78 (Fig. 2). Furthermore, numerical modeling of the two main long-wavelength mantle convection patterns-degree 1 mantle flow and degree 2 mantle flow)-shows that they are related to supercontinents ${ }^{74,76}$. For example, one hypothesis is that the supercontinent cycle causes an alternation between the dominance of degree 1 and degree 2 long convective wavelengths ${ }^{74,76}$. Initially, supercontinent assembly is dominated by degree 1 mantle flow where continents would collect over the hemispheric superdownwelling. Several processes (the relative importance of which is debated ${ }^{74,79,80}$ ) combine to turn the region of downwelling beneath the supercontinent into one of upwelling. The supercontinent becomes encircled by subduction zones and geodynamic models indicate that return flow from subduction may be an important contributor to this transformation ${ }^{74}$. Mantle convection is thus transformed from degree 1 into degree 2, in which two antipodal regions of upwelling are bisected by a subduction girdle [G] of downwelling ${ }^{74,76}$.

Presently, whether the degree 2 mantle flow pattern inferred from data (Fig. 2) and modelling ${ }^{74,76}$ is supercontinent-induced or whether it already existed is debated ${ }^{75,81}$. There are two competing end-member hypotheses about the origin of the mantle flow pattern and its relation to supercontinent formation. First is the stationary or quasistationary hypothesis ${ }^{51,53,54,56,75}$ that the degree 2 pattern (as represented today by two antipodal LLSVPs under the African and Pacific plates) is relatively stable and long-lived, that is, degree 2 existed before supercontinent Pangaea formed or moved above one of current LLSVP locations. Second is the dynamic hypothesis ${ }^{73,74,76,77,81-84}$ where degree 2 flow reflects coupling between the supercontinent cycle and convecting mantle with a new LLSVP forming beneath the nascent supercontinent.

Both end-member hypotheses have unresolved issues. The stationary hypothesis has the geodynamic problem of how a supercontinent would form or move over an LLSVP (Fig. 2 ), which is presumably associated with an upwelling, with divergent flow in the shallow mantle, and a dynamic topography high ${ }^{74,83,85}$. Rather, continents are expected to drift toward downwellings and dynamic topography lows 86,87 between the two LLSVPs, as observed in the dispersion of continents since the breakup of Pangaea ${ }^{58-60}$. The dynamic hypothesis, by design, cannot rely on the detailed seismically inferred structure of the present-day lower mantle (Fig. 2), and thus most of the evidence purported to support the coupling between supercontinents and the mantle is indirect (for example, TPW ${ }^{60}$, 
LIP cyclicity ${ }^{76,82}$, and geochemistry ${ }^{81}$ ), or involves back-calculating mantle structure with numerical modelling as influenced by plate tectonics reconstructions ${ }^{73,77}$, both of which have large uncertainties.

Pangaea is ultimately the keystone that upholds the concept of what a supercontinent is and the detailed understanding of it provides the central principles on which the understanding of older supercontinents depends. But there are also aspects of Pangaea that are unique to this most recent supercontinent. Pangaea was where the dinosaurs roamed and provided the ecosystem in which the abundant fossil record of Phanerozoic flora and fauna evolved ${ }^{88}$. After Pangaea assembly, the concentration of atmospheric oxygen reached its zenith in Earth history because forests and vegetation flourished 89,90 . Burial and decay of vegetation-rich sediments then formed the vast Carboniferous coal deposits ${ }^{89}$. Finally, rifting processes during the breakup of Pangaea are associated with some of the largest oil and gas reserves on Earth, such as the Persian Gulf and Gulf of Mexico $^{91}$.

\section{[H2] Rodinia and Columbia}

Peaks in global isotopic ages $92-95$ and other geologic occurrences ${ }^{96,97}$ indicate the likelihood of at least two pre-Pangean supercontinents: Rodinia at ca. $1 \mathrm{Ga}^{98-104}$ and Columbia at ca. $1.5 \mathrm{Ga}^{23,32,39,105-114}$ (Columbia has also been referred to as Nuna, but a solution to the semantic standoff is that Nuna represents a precursor megacontinent [G] building block of the larger supercontinent of Columbia, much like Gondwana was a precursor to Pangaea115). Palaeogeographic reconstructions in Precambrian time are inherently controversial given the lack of constraints from seafloor spreading that make the first-order reconstruction of Pangaea comparatively straightforward ${ }^{116}$. Nonetheless, great strides have been taken to reconstruct pre-Pangaean supercontinents ${ }^{10}$.

The reconstructions of pre-Pangaean supercontinents depicted (Fig. 1) have not yet reached a level of consensus, as many uncertainties and debates remain 10,36. For example, in supercontinent Columbia it is debated whether Siberia had a tight fit ${ }^{106,117,118}$ or a loose fit ${ }^{119,120}$ with Laurentia. Although some aspects of the configuration are debated, there is generally first-order agreement on the existence of both pre-Pangaean supercontinents and their general timing of assembly and breakup (Columbia, ca. 2.2-1.2 Ga; Rodinia ca. 1.2-0.6 Ga; Pangaea, ca. 0.6 Ga to present), and several relative continental configurations are becoming more widely accepted (Fig. 1). Furthermore, the most quantitative means of supercontinent reconstruction in deep time, apparent polar wander (APW) [G] path comparison (Box 1) measured with palaeomagnetism [G] assuming a geocentric axial dipole [G], has been effectively applied to both Rodinia and Columbia and tested independently by more qualitative means, such as the correlation of geologic piercing points [G] (Box 1).

It has been suggested that Rodinia was geologically distinct from both Columbia and Pangaea ${ }^{97,121,122}$, in that Rodinia is relatively poorly endowed in mineral deposits ${ }^{123}$ and is also the only one of the three known supercontinents to have experienced low-latitude Snowball Earth glaciations $\mathbf{s}^{124-126}$. The configuration of Rodinia is thought to have played a central role in the development of Snowball Earth. For example, the dominantly tropical to subtropical distribution of Rodinia's continents 127 likely facilitated global-scale glaciation by enhanced drawdown of $\mathrm{CO}_{2}$ owing to increased continental weathering ${ }^{103,126}$. The late Neoproterozoic Cryogenian Period of Snowball Earth episodes 
(720-635.5 Ma) coincided with the rifting of Rodinia and increased glacial erosion ${ }^{128}$ (with deep glacial incisions occurring in rift-related uplifted horsts ${ }^{129}$ ), processes which collectively influenced the geochemical carbonate-saturation state of the oceans ${ }^{130}$. The uniqueness of Rodinia might relate to a contrasting style of tectonic assembly with that of other supercontinents $97,121,122$.

Columbia is Earth's oldest-known supercontinent. Columbia assembled during ca. 2.0-1.6 $\mathrm{Ga}$, beginning with the formation of its core (the megacontinent of Nuna ${ }^{106,115}$ ) during the Thelon orogen $1970 \mathrm{Ma}^{131}$, where the Rae craton served as the upper plate in the collisions that formed Laurentia as part of the larger Nuna ${ }^{132}$. Progressive assembly of Columbia continued until the final suturing of Australia at ca. $1.6 \mathrm{Ga}^{133}$, which was located along the periphery of Columbia ${ }^{39,108}$. The occurrence of voluminous anorogenic graniteanorthosite complexes (granitoids crystallised from a magma with low water content and lacking tectonic fabrics), characteristic of middle Proterozoic time, suggests extensive and prolonged melting of the crust and mantle. In the absence of evidence for either crustal stretching (which would cause decompression melting) or subduction (hydrous melting), this magmatism has been widely attributed to mantle upwelling beneath a supercontinent ${ }^{134}$. Such observations led to the speculation that this upwelling occurred beneath the Palaeoproterozoic-Mesoproterozoic supercontinent Columbia, providing evidence for Earth's first true supercontinent ${ }^{134}$. It should also be noted that Columbia is the most endowed supercontinent in terms of mineral deposits ${ }^{123}$, however, the reasons for this abundance remain unclear.

Evidence of plate tectonics coupling with mantle convection can be deduced from the geologic record for pre-Pangaean supercontinents, albeit less directly than comparison with present-day mantle seismic structure (Fig. 2). Like Pangaea, both Proterozoic supercontinents exhibit a close association with mantle-related anomalies, for example rifts and LIPs sourced from mantle plumes ${ }^{39,102,103,106,117,135,136}$ and intervals of TPW whereby the spin axis approximately follows a great circle orthogonal to an axis central to each supercontinent ${ }^{60,64,65,137-141}$, both controlled by the sub-supercontinent mantle upwelling.

\section{[H2] Unknown Archaean}

The history of crustal growth during Earth's early evolution is hotly debated ${ }^{142-144}$, although most models propose that a majority of Earth's continental crust formed prior to the assembly of Columbia ${ }^{145}$. If crustal volume was insufficient during Archaean time to affect mantle convection patterns, or if underlying Archaean mantle flow occurred on shorter wavelengths with many small cells (possibly because of a hotter ambient mantle ${ }^{146}$ ), crustal assembly into a truly large supercontinent might not have occurred until a threshold volume of continental crust was attained.

Archaean cratons are uniformly bounded by Proterozoic rifted margins, implying inclusion in some ancestral landmass(es) ${ }^{105}$. A cycle of continental assembly and breakup appears to operate in Late Archaean times, inspiring speculation about the possibility of an Archaean supercontinent, dubbed Kenorland ${ }^{147}$. Unlike Columbia and Rodinia, however, no robust near-global reconstructions have been made for time intervals of either assembly or breakup of the putative Kenorland. The only palaeomagnetic reconstructions of Kenorland that have been made thus far are single-pole comparisons, in other words, constrained by palaeomagnetic poles of only one age ${ }^{148,149}$. Even though 
single-pole comparisons effectively compare palaeolatitude, they are completely unconstrained in the relative palaeolongitude of component blocks. For example, Australia and South America are presently at similar latitudes, but they are widely separated in longitude by the large Pacific Ocean. APW path comparisons (Box 1), with a precision comparable to those of Proterozoic supercontinents, have yet to be done for Archaean cratons owing to the general paucity of palaeomagnetic data from most cratons.

Thus, interpretations of late Archaean palaeogeography have relied on geologic means of correlation, using approaches such as comparing magmatic barcodes [G] ${ }^{150,151}$ (Box 1) . As an alternative to an Archaean supercontinent, the existence of smaller and segregated supercratons [G] has been proposed, in which clusters of cratons occurred without them ever becoming connected ${ }^{152}$. The appeal of the supercratons hypothesis is that it can explain the long-known diachroneity of late Archaean cratonization153,154. Reconstructions based primarily on emplacement ages of radiating dyke swarms ${ }^{155}$,

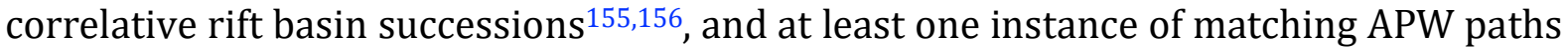
of two cratons ${ }^{157}$ are consistent with the idea of a supercraton called Superia surrounding the Superior craton. There is also at least one instance of an APW path comparison between cratons suggesting that Yilgarn and other cratons were most likely not a part of Superia, which is inconsistent with a single Archaean supercontinent and supportive of the existence of another supercraton geographically distant from Superia ${ }^{158}$.

Distinguishing between these rival hypotheses of Archaean-Proterozoic continental clustering has implications for mantle convection. A few factors could have prevented the dominance of large-scale flow, such as small sizes, and/or short durations of continental clusters ${ }^{80}$, and/or the lack of a global subduction girdle that could have been the primary driver for the formation of LLSVPs 76,102 . The proposed connection between Kaapvaal and Pilbara cratons (known as the Vaalbara connection) could have produced a small composite craton that was possibly long-lasting (ca. 2.8-2.1 Ga) ${ }^{159}$, but its existence has been called into question on palaeomagnetic grounds ${ }^{160}$. Without contiguity with other cratons (if any), the relatively small size of continental area would have likely been insufficient to steer mantle convection towards dominance of the very large scales such as degree 1 and degree 2 flow.

As currently reconstructed 155,158 , the Superia supercraton is estimated to have been about the size of modern-day Antarctica, and so is much smaller than any of the three established supercontinents ${ }^{74,80}$ (Fig. 1). Superia might have been larger than Antarctica ${ }^{152}$, but it is thought that Superior was the predominant craton of Superia surrounded by multiple potential neighbours (for example, Wyoming, Karelia and Kola, Hearne). Palaeogeographic reconstructions can ultimately distinguish between the supercontinent and supercratons hypotheses for Archaean-Proterozoic time but our present understanding suggests that Archaean supercratons ${ }^{152}$ were likely not large enough to either cause or affect a dominant degree 1 or 2 structure for underlying mantle convection patterns.

Proterozoic continents and Archaean cratons are notably different in size, with $\sim 4$ cratons on average contained within the area of each Proterozoic continent ${ }^{152}$. Thus, the difference between the scale of mantle convection patterns beneath supercontinents and supercratons - if there is a difference in convective length scales - is arguably reflected in the different surface area sizes of their rifted blocks ${ }^{152,161}$. According to inference, 
Archaean mantle convective cells associated with supercratons might have only been $<40 \%$ the size of their Proterozoic-Phanerozoic successors associated with supercontinents.

Smaller Archaean convective cells can account for the episodic, intermittent nature of Archaean subduction ${ }^{162,163}$. It is therefore possible that Archaean mantle convection was exclusively characterized by higher harmonics and/or random mantle flow. More randomised Archaean convection could provide a viable explanation for why segregated supercratons might not have amalgamated into a supercontinent, as they were quarantined within shorter-wavelength convection cells instead of degree 1 and degree 2 planforms.

\section{[H1] Supercontinent dynamics}

Building on the general palaeogeographic evidence for the existence of multiple supercontinents over the last $\sim 2$ Gyr, we explore how the kinematics of the supercontinent cycle can be explained by the coupling between plate tectonics and mantle convection. Numerical modeling sheds light on these geodynamic processes (Fig. 3 ) as well as the role of mantle convection in top-down versus bottom-up tectonics (Box 1).

\section{[H2] Mantle flow}

Despite its theoretical plausibility and a wealth of empirical evidence, the coupling between mantle convection and plate tectonics remains controversial ${ }^{1}$. Both evidence and modeling suggest that supercontinents are both an effect and a cause of mantle convection ${ }^{60,74}$. This feedback is exhibited in the convergence and assembly of continents over dynamic topography lows induced by mantle downwelling, followed by circumsupercontinent subduction during which subcontinental mantle flow evolves into an upwelling owing to return flow $74,76,102$. The origin of Earth's present long-wavelength mantle structure and inferred flow pattern, which closely reflects the breakup of supercontinent Pangaea (Fig. 2), is therefore intimately related to supercontinent formation.

A genetic relationship between large-scale mantle flow and the dynamics of the supercontinent cycle is commonly assumed $64,74,76,86,164$, although deciphering the evolution of such convective models throughout Earth history has remained elusive. Numerical simulations of mantle convection ${ }^{74}$, particularly those including the influence of continents 164,165 , starting with random flow (Fig. 3a) arrive at degree 1 structures as smaller downwellings (or upwellings) gradually merge together until only one of each remain (superdownwelling and superupwelling, respectively) and are antipodal (Fig. $3 b)$. Supercontinent formation is a likely, if not inevitable, outcome of degree 1 flow as continents would converge towards and then aggregate over the developing mantle superdownwelling $74,76,86$, though subduction zone initiation elsewhere can modify such a degree 1 planform ${ }^{166}$.

Supercontinent amalgamation could facilitate the transition from degree 1 to degree 2 convective mantle flow though converting the superdownwelling into a superupwelling ${ }^{74}$, but the processes involved are debated. One contributing factor is that the downwelling might stop when subduction terminates between converging continental blocks and the corresponding slabs sink to the base of the mantle ${ }^{83}$. Another 
contributing factor is the establishment of subduction around the supercontinent periphery causing upwelling via mantle return flow ${ }^{74}$. The end result is the establishment of a second superupwelling antipodal to the first superupwelling bisected by a girdle of downwelling producing a subduction geometry similar to what is observed today along the 'ring of fire' surrounding the Pacific Ocean (Fig. 2, 3c). In this scenario, there is a feedback between mantle convection and supercontinent formation, where mantle convection can facilitate supercontinent assembly, but then the newly formed supercontinent causes profound changes to mantle convection patterns.

The evolution of mantle flow to long convective wavelengths would have increased the efficiency of convective heat transfer and thus enhanced core-mantle boundary heat flux $^{74,167,168}$ (Fig. 3d,e). Results are shown for two cases: the transition from smaller-scale to predominantly degree 1 mantle convection corresponding to the formation of the first supercontinent (Fig. 3d), and the transition from predominantly degree 1 to degree 2 convection after supercontinent formation (Fig. 3e). Interestingly, although estimates for the age of inner core nucleation range widely from $1.5 \mathrm{Ga}^{169}$ to $600 \mathrm{Ma}^{170}$, both these ages post-date the known occurrences of supercontinents. Both the onsets of a global-scale subduction network ${ }^{23}$ and long-wavelength mantle convection were requirements for the supercontinent cycle. Both of these prerequisites would have accelerated planetary cooling owing to cool slabs descending to the core-mantle boundary and through more efficient convection. Thus, secular cooling would have eventually led to formation of an inner core, although these two features of the supercontinent cycle (a global subduction network and efficient long-wavelength mantle convection) might have accelerated cooling of the core promoting inner core nucleation a billion or so years before it might have occurred without supercontinents (Fig. 3).

\section{[H2] Mechanisms of assembly and breakup}

Both top-down and bottom-up geodynamic processes are important for supercontinent assembly and breakup, as well as how they are coupled. Forces acting on the plates themselves in combination with interaction with the convecting mantle facilitate continental convergence and divergence. Slab-pull force is the largest, but basal traction owing to coupling between the continental lithosphere and the convecting mantle is considerable and almost as large ${ }^{58}$. Although these two forces can be opposed to each other, more typically they are coupled to convective mantle downwelling ${ }^{59}$, and thus reinforce one another. In geodynamic models, continents therefore tend to drift downhill, that is, towards dynamic topography lows, thus forming a supercontinent above a mantle downwelling74,86. Notably, the present-day subduction girdle surrounding the Pacific Ocean (also known as the "ring of fire") coincides with the degree 2 girdle of mantle downwelling in between the two LLSVPs. This observation is thus consistent with the theoretical expectation that continents drift towards, and eventually collect above, downwellings. Supercontinent assembly is thus dependent on the wavelength of mantle flow. The longest wavelength, degree 1 mantle flow (Fig. 3b), is also favoured owing to Earth's characteristic viscosity profile, which has a weak upper mantle inserted between the underlying strong lower mantle and the overlying rigid lithosphere ${ }^{74,171}$. Thus, the superdownwelling of degree 1 flow is often invoked to facilitate supercontinent assembly ${ }^{73,74,76 \text {. }}$

It has been proposed that a megacontinent ${ }^{115}$ (for example, Gondwana) is a geodynamically important precursor to supercontinent amalgamation ${ }^{172,173}$. The 
presently ongoing assembly of Eurasia is considered as the fourth and most recent megacontinent associated with future supercontinent Amasia60,174,175. As continents disperse after supercontinent breakup, a megacontinent assembles along the subduction girdle that encircled it, at a specific location where the downwelling is most intense. Such a situation occurs today as continents aggregate over a mantle downwelling beneath south-central Asia ${ }^{58,176}$ close to where the Tethys sutures connect to the degree 2 circumPacific subduction girdle. In this context, the formation of Eurasia as a megacontinent occurs close to the degree 1 (or dipolar) locus of downwelling along the degree 2 girdle.

After the megacontinent forms, however, the intensity of local downwelling eventually diminishes owing to both return flow from circum-megacontinent subduction and subcontinental insulation ${ }^{74,177}$, thus potentially generating plumes underneath the megacontinent and slab rollback along its periphery, as both observed in early Paleozoic Gondwana ${ }^{173}$. As the downwelling beneath the megacontinent diminishes so that it becomes less intense than elsewhere along the girdle, the megacontinent will likely migrate along the girdle where it can collide with other continents to form a supercontinent ${ }^{115}$. It is the eventual development of a degree 2 mantle upwelling beneath a young supercontinent that might explain why we do not seem to see supercontinents straddling the poles (Fig. 1), as TPW64,71 would tend to shift the newly developed antipodal degree 2 upwellings to the equator ${ }^{139}$ (Fig. 2), if the supercontinent did not already form there.

The dynamics of supercontinent breakup are arguably less well understood than for supercontinent assembly, not because of a lack of sources of stress, but rather because there is little consensus on the relative importance of these stresses required for breakup. Various potential sources of extensional stress for supercontinent breakup, both topdown (slab induced) and bottom-up (mantle induced) can be compared (Box 2).

In terms of observations, the ages of internal oceans that opened during the breakup of Pangaea provide valuable constraints on the timing and geometry of supercontinent breakup ${ }^{178}$. The continents have rifted away from Africa in the centre, which itself is still positioned over the African LLSVP. This observation suggests that plume push plays a major role in the initial rifting, consistent with modelling, although the plume push force is transient ${ }^{179}$. Also, plumes can weaken the lithosphere as hot plume material feeds into existing rifts and sutures, where the lithosphere is already thinned, helping to trigger final continental breakup by enhancing the continent's sensitivity to other stresses ${ }^{180-183}$. In some cases, plume induced melts can facilitate rifting of even initially thick cratonic lithosphere through such thinning ${ }^{181,183}$. The emplacement of LIPs is either a cause or an initial manifestation of breakup, for example, the ca. 200 Ma Central Atlantic Magmatic Province $\sim 20$ Myr before seafloor spreading initiated.

The drifting of continents away from Africa is highly diachronous, with the Central Atlantic Ocean opening during the initial rifting of North America from Africa which occurred $\sim 40$ Myr before the opening of the South Atlantic Ocean during the rifting of South America ${ }^{178}$. North America broke away (and soon thereafter South America as well) from elevated tensile stress beneath Africa (Box 2), where mantle upwelling from the African LLSVP is located today and likely was then too ${ }^{58}$ (Fig. 2). 
Slab rollback has also been argued to be an important force in supercontinent breakup ${ }^{184}$, but a sensitivity analysis conducted with numerical modelling suggests that it is arguably secondary to plume push ${ }^{179,185}$. Plume push is a larger but transient force that affects the supercontinent more centrally and broadly, whereas slab rollback force is intermediate in strength but persistent and affects mostly the margin of the supercontinent ${ }^{179}$. Both slab- and mantle-induced stresses can combine to contribute to breakup of a supercontinent, where a model result (Box 2) indicates that the associated top-down and bottom-up stresses are not only roughly equal in magnitude, but also constructively interfere. Thus, both top-down and bottom-up stresses are important and should also not be thought of as mutually exclusive in their effects.

\section{[H2] Models of supercontinent formation}

Earth's present-day geography is in-between supercontinent configurations and represents a temporal overlap between the assembly of the next supercontinent (recent collision between Asia and India ca. 40 Myr ago, future collision of Australia) and the protracted breakup of Pangaea (East African rift). The hypothetical configuration of the next supercontinent is an illustrative way to compare and contrast models of supercontinent formation. Introversion [G] predicts the Atlantic Ocean will close. Extroversion [G] predicts the Pacific Ocean will close. Orthoversion predicts the smaller tracts of seafloor-the Arctic and Caribbean Seas and either the Indian Ocean or Scotia Sea-orthogonal with respect to the centroid (located in Africa) of Pangaea will eventually close. We briefly discuss the assumptions behind each of these models and possible tests to distinguish between them using the historical record of supercontinents, geodynamic modeling, and igneous geochemistry.

Introversion and extroversion are strictly tectonic models as they are, at least as presently defined, predictions about which ocean will close: Atlantic-type or Pacific-type. The Atlantic Ocean is said to be an internal ocean as it opened up during the breakup of Pangaea. Supercontinent assembly by the closure of the internal ocean, or introversion ${ }^{7}$, is essentially where a supercontinent would converge inward on itself, possibly because of incomplete breakup ${ }^{97}$ or dispersal, thus amalgamating in a similar location to the previous supercontinent. The Pacific Ocean on the other hand was external to Pangaea and supercontinent assembly by extroversion ${ }^{186-188}$ stipulates that rifted continents continue to drift apart until this external ocean closes. As a result, the previous supercontinent is turned inside-out as its successor amalgamates.

Another way to compare introversion and extroversion is the inheritance or the regeneration, respectively, of the circum-supercontinent subduction girdle ${ }^{97}$. The presence of cycles in geochemical data and geologic occurrences that are as long as twice the duration of the supercontinent cycle have been used to argue for a longer period modulation ${ }^{94}$, possibly because of alternation between supercontinents formed by introversion and extroversion ${ }^{97,189}$.

In contrast, orthoversion is a geodynamic model that predicts a succeeding supercontinent forms $90^{\circ}$ away from the previous one, within the great circle of subduction encircling its relict predecessor ${ }^{60}$. On present Earth, orthoversion would thus predict one of those seas located along the subduction girdle to close, instead of the Pacific or the Atlantic oceans. It has been proposed that, after supercontinent assembly, long-wavelength mantle convection develops an upwelling beneath the supercontinent, 
which is associated with a geoid high ${ }^{83}$. In combination with the antipodal geoid high, a prolate shape of the non-hydrostatic Earth develops, with the minimum inertia axis centered within the supercontinent. Mass anomalies in the mantle related to tectonics and convection induce TPW, which follows a great circle around this minimum inertia axis in order to align the spin axis with the maximum moment of inertia. Identification of TPW migrations about such an axis has been proposed as a method for locating the centre of a supercontinent and appears to support the geodynamics of orthoversion as supercontinent centres shift $\sim 90^{\circ}$ in palaeolongitude from one supercontinent to the next ${ }^{60}$.

Igneous geochemistry provides a clear test between introversion and extroversion with either Sm-Nd or Hf isotopic evidence ${ }^{121,190}$. Both of these isotopic systems can be used to fingerprint arc magmatic systems dominantly characterized by crustal reworking or mantle-derived magmatism ${ }^{38,121}$. The Pacific subduction girdle would eventually develop into double-sided subduction with dominantly mantle-derived magmatism, whereas Tethyan subduction systems are characterized by single-sided subduction with dominantly crustal reworking ${ }^{191}$. Therefore, introversion would be consistent with evidence for increased crustal reworking owing to single-sided subduction and leading to internal collisional orogens. Alternatively, extroversion would produce increased juvenile, mantle-derived, magmas during double-sided subduction leading to external collisional orogens ${ }^{190}$.

Such contrasting geochemical and isotopic signatures correspond with the contrasting collisional styles of Rodinia and Gondwana (early stage in formation of Pangaea) ${ }^{121}$. It is argued by some researchers that the assembly of Rodinia was characterized by melting juvenile crust and is more consistent with extroversion, whereas the assembly of Gondwana is characterized by the melting of old crust, more consistent with introversion ${ }^{121}$. Other scientists, however, argue for an opposite scenario where Rodinia formed by introversion, based more on palaeogeographic considerations ${ }^{97}$. Isotopic predictions for orthoversion ${ }^{60}$ are less clear, but would likely involve a mixture between the end-member predictions of introversion and extroversion ${ }^{192}$.

\section{[H1] Proxies and patterns}

Although there continues to be considerable debate over their configurations, there is broad consensus on when individual continents assembled and rifted away from each supercontinent (Fig. 1). Irrespective of their configurations (Fig. 1), recurring supercontinent cycles of continental assembly and breakup through time are clearly evident in both geological and geochemical proxies ${ }^{96}$. Furthermore, the same proxies that provide a time series of supercontinent cycles also suggest secular shifts indicating that the onset of supercontinents was an irreversible state change.

\section{[H2] A supercontinent cycle time series}

Geological proxies recording supercontinent cycles include the timing and locations of large igneous provinces ${ }^{82}$, passive margins ${ }^{193}$, orogens ${ }^{194}$ and mineral deposits ${ }^{97}$. Igneous geochemistry offers additional insights into supercontinent dynamics by fingerprinting processes such as subduction (arc magmatism), crustal reworking (collisional orogenesis), and mantle heat flow (plume magmatism). Signals of a supercontinent cycle have been detected in the ages and $\mathrm{Hf}$ isotopic compositions of robust accessory minerals such as zircon ${ }^{38,92}$ as well as the $\mathrm{MgO}$ content of plume-derived basalts ${ }^{195}$. Comparison of 
the variations of these isotopic proxies with the historical record of supercontinents offers a more complete understanding of the tectonic processes related to the supercontinent cycle.

Building on this consensus of robust patterns in temporal proxies for the supercontinent cycle, we explore how geochemistry can be used to depict a timeline of assembly and breakup of the past three supercontinents. Orogenesis during supercontinent assembly should considerably increase the volume of supracrustal reworking in the magmatic systems relative to mantle values ${ }^{196}$, as has been argued for using $\mathrm{Hf}$ isotopes of zircon showing fluctuations between crustal reworking (supercontinent assembly) and mantlederived magmatism (supercontinent breakup) ${ }^{37,38}$.

The degree of continental contribution in magmatic systems can also be assessed with a compilation of zircon $\delta^{18} 0$ measurements, a well-established proxy for the relative contributions of mantle and supracrustal material ${ }^{197}$. A global compilation ${ }^{196}$ of oxygen isotopes in $\sim 15,000$ zircons through time includes analyses made by conventional laser fluorination and secondary ion mass spectrometry (Supplementary Table 1) and was tested here for statistically significant variability using change-point analysis following the technique of REF. ${ }^{198}$. This statistical technique ${ }^{199}$ reveals only change points if the null hypothesis of no change (that is, one mean value) can be rejected. The change points are automatically assigned by the outcome of this statistical test. The change-point analysis on oxygen isotopes of zircon reveals increased crustal reworking associated with the assembly phases of each of the three supercontinents (Fig. 4).

During the breakup phase of each of the three supercontinent cycles, $\delta^{18} 0$ values decrease, trending toward more mantle-like values (+5\%o), which is consistent with models invoking more mantle-derived magmatism associated with either mantle plumes and/or slab rollback during supercontinent breakup (Fig. 4). Using geochemical proxies such as hafnium ${ }^{37,38}$ and oxygen (Fig. 4) isotopes on well-dated zircons thus establishes a statistical basis for the supercontinent cycle.

\section{[H2] A supercontinent state}

It is debatable whether the supercontinent cycle existed before ca. $2 \mathrm{Ga}$. A global cycle of continental assembly and breakup of roughly $\sim 600 \mathrm{Myr}$ might have existed before $2 \mathrm{Ga}$, but large supercontinents might still have not formed-there is presently no compelling evidence that any pre-Columbia supercontinent existed. Secular change as the planet evolved is one of the possible reasons that supercontinents might not have formed until later in Earth history (Box 3).

The same proxies used here for a supercontinent cycle time series also suggest a supercontinent state of cyclic variations has existed only since ca. 2 Ga (Fig. 4). Two types of variations in $\delta^{18} 0$ values of zircon can be identified, these are: oscillating signals in synchronicity with collisional assembly of supercontinents (a supercontinent cycle time series); and a single state shift as the planet evolved from one tectonic regime to another (a supercontinent state). A state shift-a shift from one state to another-can be caused by either a threshold or a sledgehammer effect ${ }^{200}$. An example of a sledgehammer effect is the sudden increase in river discharge because of flooding following a rainstorm. Incremental change that eventually exceeds a particular threshold value is more difficult 
to detect, but either type of state shift can cause the system to begin to operate within a range of variability outside that of its previous state.

The short-term variations in the $\delta^{18} 0$ supercontinent cycle time series do not appear until ca. 2.4 Ga (Fig. 4), that is, immediately after the long-term shift into the modern supercontinent state as evidenced in the geochemistry of both mafic and felsic rocks (Box 3). Thus, geochemical proxies depict both supercontinent cycles (rhythms) as well as manifestations of secular change (trends) ${ }^{195}$. Secular change in the crust is largely thought to be manifest in the growth and emergence of the continents ${ }^{144}$. Evidence of both more crustal volume and more crustal volume above sea level should result in a notable increase $\left(\sim 1 \%\right.$ o $\left.\delta^{18} 0\right)$ in supracrustal reworking in the magmatic systems associated with orogenesis ${ }^{196}$. As indicated by $\delta^{18} 0$ values, time intervals typified by increased supracrustal reworking are associated with modern supercontinents, whereas the $\delta^{18} 0$ record before ca. $2.4 \mathrm{Ga}$ is invariant and typified by mantle-like values (Fig. 4). The supercontinent state thus likely reflects secular evolution from ancient stagnantand/or mobile-lid tectonics $26,201,202$ with plate tectonics localized to ocean arcs, to the modern global plate tectonic network involving all continents 23,24 .

\section{[H1] Implications for Earth history}

In addition to being an integral part of a linked plate tectonic and mantle convective theory, the supercontinent cycle likely influenced the course of Earth history. It has been hypothesized that a uniquely pronounced tectono-magnetic lull (TML) occurred ca. 2.3 $\mathrm{Ga}$, in between the transition from supercratons and supercontinents (Fig. 4), and thus possibly serving as a trigger for the supercontinent cycle ${ }^{203}$. Assuming Columbia was Earth's first true supercontinent (Fig. 1), the onset of the supercontinent cycle (Fig. 4; Box 3) was likely characterized by the appearance and dominance of long-wavelength mantle convection (for example, degree 1 and degree 2 structures; Figs 2 and 3). In combination with secular changes including long-term planetary cooling and increased lithospheric viscosity contrast, the appearance of supercontinents in Proterozoic time and the increased convective wavelength of the mantle might have been inevitable and irreversible.

A Proterozoic onset (Box 3) of long-wavelength mantle convection (Fig. 3) would carry implications for the earliest presence of thermochemical piles ${ }^{204}$ on the core-mantle boundary - the most common explanations for the LLSVPs seismically observed today (Fig. 2), although other interpretations have been proposed to explain the same seismic structures ${ }^{205}$. The compositional origins of the LLSVPs could date as far back as Hadean magma ocean solidification, where crystallisation caused the settling of dense particles at the base of the mantle ${ }^{206}$. Such a model of a globally homogeneous layer, however, cannot explain why the mantle evolved to generate two LLSVPs that straddle the equator and are antipodal with respect to one other (Fig. 2), an outcome that requires the onset of whole mantle convection in the form of degree 2 flow (Fig. 3b).

The present-day antipodal lower mantle structures appear to have been shaped by circum-supercontinent subduction, where the African LLSVP matches closely the location of supercontinent Pangaea at ca. $200 \mathrm{Ma} \sim 20$ Myr before breakup52,78 (Fig. 2). An onset of long-wavelength mantle convection associated with supercontinent Columbia might have thus organized the previously primordial global layer of dense particles into two antipodal LLSVPs owing to the dominance of degree 2 mantle convection during 
supercontinent tenure and breakup (Fig. 3c). Alternatively, it has been argued that the two LLSVPs are not only compositionally ancient but so is their convective organization which, according to this viewpoint, pre-dates Earth's first supercontinent ${ }^{75}$.

It is also possible that compositional heterogeneities in the mantle that resulted from Hadean core-mantle differentiation, identified by short-lived ${ }^{146} \mathrm{Sm}-{ }^{142} \mathrm{Nd}$ isotope systematics 207 , could have persisted until Proterozoic time, after which the mantle was sufficiently mixed to homogenize ${ }^{142} \mathrm{Nd}$. Note that suggested ${ }^{142} \mathrm{Nd}$ isotopic anomalies as young as ca. $1.5 \mathrm{Ga}^{208}$ are now considered laboratory artifacts ${ }^{209}$. On the other hand, ${ }^{182} \mathrm{~W}$ isotopic anomalies are found in young rocks ${ }^{210}$ and so must be comparatively resistant to homogenization by mantle mixing. If regions of anomalous ${ }^{182} \mathrm{~W}$ can remain isolated in deep pockets either near the core/mantle boundary ${ }^{211}$ or within silica-enriched domains in the lower mantle ${ }^{212}$, then this isotopic system could be used to investigate the nature of primordial signatures rather than the process of their homogenization since Hadean time ${ }^{213}$. A paucity of ${ }^{142} \mathrm{Nd}$ data between 2.7 and $0.8 \mathrm{Ga}^{214,215}$ presently precludes testing whether the ${ }^{142} \mathrm{Nd}$ Hadean differentiation signature was ultimately obliterated by early Archaean convection and the birth of plate tectonics ${ }^{29}$ or by early Proterozoic longwavelength convection and the birth of the supercontinent cycle (Fig. 4; Box 3).

Finally, the birth of supercontinents might have influenced Earth's surface evolution 5,6,1114. Following the Great Oxidation Event ca. 2.4-2.3 Ga ${ }^{216}$, the occurrence of repeated episodes of glaciation on some (but not all) cratons ${ }^{158}$ and documented on supercraton Superia ca. 2.5-2.2 $\mathrm{Ga}^{155}$, indicates that some continental crust already had positive continental freeboard [G] above sea level ${ }^{198,217}$. Nonetheless, there are as many cratons that do not have evidence for Early Proterozoic glaciation as those that do ${ }^{158}$. The conspicuous absence of such glaciations on many other cratons (for example, Dharwar, Sao Francisco, Slave, Yilgarn, Zimbabwe) suggests that elevated continental freeboard was arguably not a global phenomenon until the amalgamation of Columbia.

A compilation of burial rates of sedimentary units over the past 4 Gyr shows a state shift decrease between 2.5 and $2.0 \mathrm{Ga}^{218}$. More continental freeboard came about because of supercontinent formation and the subsequent development of a subcontinental upwelling, causing a dynamic topography high, could have decreased accommodation space resulting in slower burial rates. Increased weathering rates associated with elevated continental freeboard of the first large supercontinent could have flooded the oceans with free ions that might have facilitated widespread biomineralization for the first time, as well as the oldest known eukaryotes ${ }^{219}$. The ca. 1880 Ma Gunflint microfossils represent the first unambiguous evidence of such widespread biomineralization 220,221 . The oldest abundant eolianites deposits in the geologic record between 2.1 and $1.7 \mathrm{Ga}$, and thus also deposited during Columbia assembly, can be accounted for by an increase in continental freeboard because of supercontinent formation necessary to source wind-blown sediments222,223.

\section{[H1] Summary and future perspectives}

The study of supercontinents is interdisciplinary research that connects mantle convection with plate tectonic theory. Earth presently has a global plate tectonic network and the repeated assembly and breakup of supercontinents is an emergent phenomenon of such a self-organizing system. It is likely that the global plate network existed by at least $2 \mathrm{Ga}^{23}$ and Earth has experienced 3 supercontinents ${ }^{10}$ since then, in the order of 
Columbia, Rodinia, and Pangaea. Palaeogeographic reconstructions of the 3 supercontinents over the past 2 Gyr have been refined (Fig. 1; Box 1), although they are still a work in progress.

Independent of palaeogeography, geological and geochemical proxies corroborate the $\sim 600 \mathrm{Myr}$ duration of the supercontinent cycle $37,38,82,96,97$. Even though a $\sim 600 \mathrm{Myr}$ period is dominant 37,38 , other cyclicities of both longer and shorter periods are present ${ }^{19,37,94,97}$ and future research needs to address the degree to which the supercontinent cycle is not simply a single cycle, but potentially a more complex ${ }^{224}$ spectrum of interacting cyclicities. Such cyclic variations arguably have only occurred for the past 2 Gyr since the onset of the supercontinent cycle (Fig. 4), suggesting that modern supercontinents are a manifestation of secular change, such as planetary cooling and tectonic evolution (Box 3). In addition to the onset of global subduction by $2 \mathrm{Ga}^{23}$, supercontinents associated with convectively efficient long-wavelength mantle convection (degree 1 and degree 2; Fig. 3) are thus consistent with increased secular cooling ever since.

Evidence from all 3 supercontinent cycles, as well as results from numerical modelling 73,74,86,165,174,175,225, indicate that supercontinent formation is intimately linked with whole mantle convection. For Pangaea, lower mantle seismic data indicate the supercontinent was positioned over a mantle upwelling above the African LLSVP (Fig. 2). A link between the LLSVP in the deep mantle and Pangaea at the surface is independently confirmed by oscillatory TPW that occurred about an axis controlled by the locations of antipodal LLSVPs ${ }^{56,63}$. Similarly large amplitude TPW has been suggested for the two Proterozoic supercontinents as well ${ }^{60,64}$. Evidence for the stability of the LLSVP beneath Pangaea is further corroborated by the emplacement of LIPs from mantle plumes preferentially emanating from the edges of the African LLSVP51,53,54,56. Earlier supercontinents also have pronounced LIP emplacement before and during breakup $39,102,106,135,136,226$, suggesting LLSVP-related mantle upwellings existed under these supercontinents as well ${ }^{76,97}$.

Continued efforts to reconstruct the palaeogeography of Proterozoic supercontinents Rodinia and Columbia are ongoing and have become increasingly interdisciplinary. Acquiring more high quality palaeomagnetic data from poorly constrained continents and cratons is required. Also, other reconstruction constraints including geological piercing points, kinematic and provenance considerations, and geological correlations must be refined independently. Efforts to integrate palaeolongitude ${ }^{60,78}$ and full-plate topologies ${ }^{99}$ into Proterozoic reconstructions are now being developed and should offer a new means of refining ancient palaeogeography.

Testing the antiquity of the supercontinent cycle and exploring the related implications for geodynamic and tectonic evolution through time are frontier questions that remain to be answered. Although the possibility of an Archaean supercontinent has not been ruled out, no compelling evidence yet exists ${ }^{158}$. The hypothesis of multiple segregated supercratons can better explain the diachroneity of the geological histories of cratons ${ }^{152}$ and is more consistent with geodynamic considerations for Archaean time. Acquiring more high-quality, well-dated palaeomagnetic poles across the Archaean-Proterozoic transition from multiple cratons offers the hope of definitively testing an Archean supercontinent versus the supercratons hypothesis. 
Despite substantial progress on linking plate tectonic theory and mantle convection, our understanding of supercontinent cycle dynamics is arguably still in its infancy. Mechanisms for both the assembly and breakup phases of the supercontinent cycle have been proposed, but the relative importance of them, particularly for breakup, are still being evaluated. It is nonetheless clear that both top-down and bottom-up tectonics and their feedbacks are important in supercontinent dynamics (Box 2). Despite a strong correlation, the dynamic link between the two antipodal LLSVPs in the lower mantle and the supercontinent cycles requires further investigation. Why the actual present-day LLSVPs are more elongated and irregular in shape (Fig. 2) than the nearly perfectly circular expressions of mantle upwellings in numerical models (Fig. 3) remains to be explored. The debate persists whether the sub-supercontinent LLSVP existed before Pangaea amalgamated, or whether the LLSVP formed as a result of Pangaea assembly. Distinguishing between hypothetical models in which LLSVPs are considered fixed for up to 2 Gyr versus LLSVPs that respond to the supercontinent cycle, is a frontier question.

\section{Key References}

\section{REF.10 (Evans, 2013)}

Offers a review of the history of efforts to reconstruct pre-Pangaean supercontinents and shows the emerging consensus, and remaining uncertainties, of each of their reconstructions.

REF.23 (Wan et al., 2020)

Reports first global-scale evidence for subduction using seismic images from multiple continents arguing for the onset of the global plate tectonic network by ca. $2 \mathrm{Ga}$.

REF. ${ }^{1}$ (Coltice et al., 2017)

Explores how geodynamic models, based on observations such as kinematics, stress, deformation, and rheology that link mantle convection and plate tectonics can take into account self-organization.

REF.58 (Conrad et al., 2013)

Shows how plate tectonic motions during the past 250 Myr have been tightly coupled with degree 1 and 2 mantle flow owing to basal tractions being nearly as strong as slab pull forces.

REF.60 (Mitchell et al., 2012)

Provides the first geodynamic model of supercontinent formation, orthoversion, where a new supercontinent will form along the degree 2 subduction girdle $\sim 90^{\circ}$ away from its predecessor.

REF.63 (Steinberger and Torsvik, 2008)

Finds oscillatory total motions of all continents using apparent polar wander (APW) that can be interpreted as true polar wander (TPW) about a stable axis near the centre of supercontinent Pangaea.

REF. ${ }^{74}$ (Zhong et al., 2007) 
Provides numerical modeling to link major modes of mantle convection (degrees 1 and 2) to supercontinent formation and TPW, with degree 1 downwelling facilitating supercontinent formation and degree 2 convection then resulting from circumsupercontinent downwelling.

REF.115 (Wang et al., 2020)

Establishes a megacontinent (for example, Gondwana) as an important geodynamic precursor to the later assembly of a supercontinent (for example, Pangaea).

REF. ${ }^{152}$ (Bleeker, 2003)

Proposes that small and segregated Archaean supercratons existed instead of one unified supercontinent based on highly diachronous tectonomagmatic events.

REF.155 (Gumsley et al., 2017)

Offers a combined geologic and palaeomagnetic reconstruction of supercraton Superia and its context in low-latitude glaciation and the Great Oxidation Event (GOE).

REF.158 (Liu et al., 2021)

Finds palaeomagnetic evidence that argues strongly in favor of segregated Archaean supercratons instead of one unified supercontinent.

REF. $^{203}$ (Spencer et al., 2018)

Finds widespread and diverse evidence for a tectonomagmatic lull at ca. 2.3 Ga that have played a critical role in triggering initiation of the subsequent modern age of supercontinents. 
References

1 Coltice, N., Gérault, M. \& Ulvrová, M. A mantle convection perspective on global tectonics. Earth-Science Reviews 165, 120-150 (2017).

2 Bercovici, D. The generation of plate tectonics from mantle convection. Earth and Planetary Science Letters 205, 107-121 (2003).

3 Stern, R. J. \& Gerya, T. Earth evolution, emergence, and uniformitarianism. GSA Today 30, doi:https://doi.org/10.1130/GSATG479GW.1 (2020).

4 Alblowitz, R. The Theory of Emergence. Philosophy of Science 6, 1-16 (1939).

5 Worsley, T. R., Nance, R. D. \& Moody, J. B. Tectonic cycles and the history of the Earth's biogeochemical and paleoceanographic record. Paleoceanography 1, 233-263 (1986).

6 Worsley, T. R., Nance, R. D. \& Moody, J. B. Global tectonics and eustasy for the past 2 billion years. Marine Geology58, 373-400 (1984).

$7 \quad$ Nance, D., Worsley, T. R. \& Moody, J. B. The supercontinent cycle. Scientific American, 7279 (1988).

8 Nance, R. D., Worsley, T. R. \& Moody, J. B. Post-Archean biogeochemical cycles and longterm episodicity in tectonic processes. Geology 14, 514-518 (1986).

9 Nance, R. D., Murphy, J. B. \& Santosh, M. The supercontinent cycle: A retrospective essay. Gondwana Research 25, 4-29 (2014).

10 Evans, D. A. D. Reconstructing pre-Pangean supercontinents. Geological Society of America Bulletin 125, 1735-1751 (2013).

11 Valentine, J. W. \& Moores, E. M. Plate-tectonic regulation of faunal diversity and sea level: A model. Nature 228, 657-659 (1970).

12 Zaffos, A., Finnegan, S. \& Peters, S. E. Plate tectonic regulation of global marine animal diversity. Proceedings of the National Academy of Sciences 114, 5653-5658 (2017).

13 Mitchell, R. N., Raub, T. D., Silva, S. C. \& Kirschvink, J. L. Was the Cambrian explosion both an effect and an artifact of true polar wander? American Journal of Science 315, 945-957 (2015).

14 Allison, P. A. \& Briggs, D. E. G. Paleolatitudinal sampling bias, Phanerozoic species diversity, and the end-Permian extinction. Geology 21, 65-68 (1993).

15 Wegener, A. The Origin of Continents and Oceans. Translated from the fourth revised edition (Braunschweig, 1929) edn, (Dover, 1929).

16 Vine, F. J. \& Matthews, D. H. Magnetic anomalies over oceanic ridges. Nature 199, 947949 (1963).

17 Wilson, J. T. Evidence from islands on the spreading of ocean floors. Nature 197, 536538 (1963).

18 Wilson, J. T. A new class of faults and their bearing on continental drft. Nature 207, 343347 (1965).

19 Wilson, J. T. Did the Atlantic close and then re-open? Nature 211, 676-681 (1966).

20 Wilson, J. T. Hypothesis of Earth's behaviour. Nature 198, 925-929 (1963).

21 McKenzie, D. P.\& Parker, R. L. The North Pacific: an example of tectonics on a sphere. Nature 216, 1276-1280 (1967).

22 Morgan, J. Rises, trenches, great faults, and crustal blocks. Journal of Geophysical Research 73, 1959-1982 (1968).

23 Wan, B. et al. Seismological evidence for the earliest global subduction network at $2 \mathrm{Ga}$. Science Advances 6, eabc5491 (2020).

24 Mitchell, R. N. et al. Plate tectonics before 2.0 Ga: Evidence from paleomagnetism of cratons within supercontinent Nuna. American Journal of Science 314, 878-894 (2014).

25 Stern, R. J. The evolution of plate tectonics. Philosophical Transactions of the Royal Society A 376, 20170406 (2018).

26 Brown, M., Johnson, T. \& Gardiner, N. J. Plate Tectonics and the Archean Earth. Annual Review of Earth and Planetary Sciences 48, 12.11-12.30 (2020).

27 Guo, M. \& Korenaga, J. Argon constraints on the early growth of felsic continental crust. Science Advances 6, eaaz6234 (2020). 
28 Rosas, J. C. \& Korenaga, J. Rapid crustal growth and efficient crustal recycling in the early Earth: Implications for Hadean and Archean geodynamics. Earth and Planetary Science Letters 494, 42-49 (2018).

29 Windley, B. F., Kusky, T. M. \& Polat, A. Onset of plate tectonics by the Eoarchean. Precambrian Research 352 (2021).

30 El Dien, H. G., Doucet, L. S., Murphy, J. B. \& Li, Z. X. Geochemical evidence for a widespread mantle re-enrichment 3.2 billion years ago: implications for global-scale plate tectonics. Scientific Reports 10, 9461 (2020).

31 Hoffman, P. F. The break-up of Rodinia, birth of Gondwana, true polar wander and the snowball Earth. Journal of African Earth Sciences 28, 17-33 (1999).

32 Meert, J. G. What's in a name? The Columbia (Paleopangaea/Nuna) supercontinent. Gondwana Research 21, 987-993 (2012).

33 Pastor-Galán, D., Nance, R. D., Murphy, J. B. \& Spencer, C. J. in Fifty Years of the Wilson Cycle Concept in Plate Tectonics Vol. 470 (eds R.W Wilson et al.) (Geological Society, 2018).

34 Ebinger, C. J. \& Sleep, N. H. Cenozoic magmatism throughout east Africa resulting from impact of a single plume. Nature 395, 788-791 (1998).

35 van Hinsbergen, D. J. J. et al. Greater India Basin hypothesis and a two-stage Cenozoic collision between India and Asia. Proceedings of the National Academy of Sciences 109, 7659-7664 (2012).

36 Evans, D. A. D., Li, Z.-X. \& Murphy, J. B. in Supercontinent Cycles Through Earth history Vol. 424 (eds Z.-X. Li, D.A.D. Evans, \& J.B. Murphy) (Geological Society, London, Special Publications, 2016).

37 Mitchell, R. N. et al. Harmonic hierarchy of mantle and lithospheric convective cycles: Time series analysis of hafnium isotopes of zircon. Gondwana Research 75, 239-248 (2019).

38 Gardiner, N. J., Kirkland, C. L. \& van Kranendonk, M. The juvenile hafnium isotope signal as a record of supercontinent cycles. Scientific Reports 6, 38503 (2016).

39 Kirscher, U. et al. Paleomagnetic constraints on the duration of the Australia-Laurentia connection in the core of the Nuna supercontinent. Geology 49, 174-179,

doi:https://doi.org/10.1130/G47823.1 (2021).

40 Irving, E. Paleomagnetism and Its Applications to Geological and Geophysical Problems. (John Wiley and Sons, 1964).

41 van der Voo, R. Paleomagnetism of the Atlantic, Tethys, and Iapetus Oceans. (Cambridge University Press, 1993).

42 Murphy, J. B. \& Nance, R. D. Supercontinent model for the contrasting character of Late Proterozoic orogenic belts. Geology 19, 469-472 (1991).

43 Murphy, J. B. \& Nance, R. D. The Pangea conundrum. Geology36, 703-706 (2008).

44 Matthews, K. J. et al. Global plate boundary evolution and kinematics since the late Paleozoic. Global and Planetary Change 146, 226-250 (2016).

45 Torsvik, T. H. et al. Phanerozoic polar wander, palaeogeography and dynamics. EarthScience Reviews 114, 325-368 (2012).

46 Irving, E. Drift of the major continental blocks since the Devonian. Nature 270, 304-309 (1977).

47 Du Toit, A. L. Our wandering continents. (Oliver \& Boyd, 1937).

48 Morel, P. \& Irving, E. Paleomagnetism and the evolution of Pangea. Journal of Geophysical Research 86, 1858-1872 (1981).

49 Tetley, M. G., Williams, S. E., Gurnis, M., Flament, N. \& Müller, R. D. Constraining absolute plate motions since the Triassic. Journal of Geophysical Research: Solid Earth 124, 72317258 (2019).

50 Domeier, M. \& Torsvik, T. Plate tectonics in the late Paleozoic. Geoscience Frontiers 5 , 303-350 (2014). 
51 Burke, K., Steinberger, B., Torsvik, T. \& Smethurst, M. Plume Generation Zones at the margins of Large Low Shear Velocity Provinces on the core-mantle boundary. Earth and Planetary Science Letters 265, 49-60 (2008).

52 Burke, K. \& Torsvik, T. H. Derivation of large igneous provinces of the past 200 million years from long-term heterogeneities in the deep mantle. Earth and Planetary Science Letters 227, 531-538 (2004).

53 Torsvik, T. H., Burke, K., Steinberger, B., Webb, S. J. \& Ashwal, L. D. Diamonds sampled by plumes from the core-mantle boundary. Nature 466, 352-355 (2010).

54 Torsvik, T. H., Smethurst, M. A., Burke, K. \& Steinberger, B. Large igneous provinces generated from the margins of the large low-velocity provinces in the deep mantle. Geophysical Journal International 167, 1447-1460 (2006).

55 Torsvik, T. H., Steinberger, B., Cocks, L. R. M. \& Burke, K. Longitude: Linking Earth's ancient surface to its deep interior. Earth and Planatary Science Letters 276, 273-282 (2008).

56 Torsvik, T. H. et al. Deep mantle structures as a reference from for movements in and on the Earth. Proceedings of the National Academy of Sciences 111, 8735-8740 (2014).

57 Doubrovine, P. V., Steinberger, B. \& Torsvik, T. H. A failure to reject: Testing the correlation between large igneous provinces and deep mantle structures with EDF statistics. Geochemistry Geophysics Geosystems 17, 1130-1163 (2016).

58 Conrad, C. P., Steinberger, B. \& Torsvik, T. H. Stability of active mantle upwelling revealed by net characteristics of plate tectonics. Nature 498, 479-482 (2013).

59 Spencer, C. J. et al. Evidence for whole mantle convection driving Cordilleran tectonics. Geophysical Research Letters 46, doi:https://doi.org/10.1029/2019GL082313 (2019).

60 Mitchell, R. N., Kilian, T. M. \& Evans, D. A. D. Supercontinent cycles and the calculation of absolute palaeolongitude in deep time. Nature 482, 208-211 (2012).

61 Chase, C. G. \& Sprowl, D. R. The modern geoid and ancient plate boundaries. Earth and Planetary Science Letters 62, 314-320 (1983).

62 Hager, B. H. Subducted slabs and the geoid: Constraints on mantle rheology and flow. Journal of Geophysical Research: Solid Earth 89, 6003-6015 (1984).

63 Steinberger, B. \& Torsvik, T. H. Absolute plate motions and true polar wander in the absence of hotspot tracks. Nature 452, 620-623 (2008).

64 Mitchell, R. N. True polar wander and supercontinent cycles: Implications for lithospheric elasticity and the triaxial Earth. American Journal of Science 314, 966-979 (2014).

65 Maloof, A. C. et al. Combined paleomagnetic, isotopic, and stratigraphic evidence for true polar wander from the Neoproterozoic Akademikerbreen Group, Svalbard, Norway. Geological Society of America Bulletin 118, 1099-1124 (2006).

66 Kent, D. V., Kjarsgaard, B. A., Gee, J. S., Muttoni, G. \& Heaman, L. M. Tracking the Late Jurassic apparent (or true) polar shift in U-Pb-dated kimberlites from cratonic North America (Superior Province of Canada). Geochemistry Geophysics Geosystems 16, 983994 (2015).

67 Fu, R. R. \& Kent, D. V. Anomalous Late Jurassic motion of the Pacific Plate with implications for true polar wander. Earth and Planetary Science Letters 490, 20-30 (2018).

68 Fu, R. R., Kent, D. V., Hemming, S. R., Gutierrez, P. \& Creveling, J. R. Testing the occurence of Late Jurassic true polar wander using the La Negra volcanics of northern Chile. Earth and Planetary Science Letters 529, 115835 (2020).

69 Creveling, J. R., Mitrovica, J. X., Chan, N. H., Latychev, K. \& Matsuyama, I. Mechanisms for oscillatory true polar wander. Nature 491, 244-248 (2012).

70 Evans, D. A. D. True polar wander, a supercontinental legacy. Earth and Planatary Science Letters 157, 1-8 (1998).

71 Evans, D. A. D. True polar wander and supercontinents. Tectonophysics 362, 303-320 (2003). 
72 Su, W. \& Dziewonski, A. M. Predominance of long-wavelength heterogeniety in the mantle. Nature 352, 121-126 (1991).

73 Zhang, N., Zhong, S., Leng, W. \& Li, Z.-X. A model for the evolution of the Earth's mantle structure since the Early Paleozoic. Journal of Geophysical Research: Solid Earth 115, B06401 (2010).

74 Zhong, S. J., Zhang, N., Li, Z. X. \& Roberts, J. H. Supercontinent cycles, true polar wander, and very long-wavelength mantle convection. Earth And Planetary Science Letters 261, 551-564 (2007).

75 Dziewonski, A. M., Lekic, V. \& Romanowicz, B. Mantle Anchor Structure: An argument for bottom up tectonics. Earth and Planetary Science Letters 299, 69-79 (2010).

$76 \mathrm{Li}, \mathrm{Z}$.-X. \& Zhong, S. Supercontinent-superplume coupling, true polar wander and plume mobility: Plate dominance in whole-mantle tectonics. Physics of the Earth and Planetary Interiors 176, 143-156 (2009).

77 Zhong, S. \& Liu, X. The long-wavelength mantle structure and dynamics and implications for large-scale tectonics and volcanism in the Phanerzoic. Gondwana Research 29, 83104 (2016).

78 Mitchell, R. N., Wu, L., Murphy, J. B. \& Li, Z. X. Trial by fire: Testing the paleolongitude of Pangea of competing reference frames with the African LLSVP. Geoscience Frontiers 11, 1253-1256 (2020).

79 Heron, P. J. \& Lowman, J. P. The impact of Rayleigh number on assessing the significance of supercontinent insulation. Journal of Geophysical Research: Solid Earth 119, 711-733 (2014).

80 Phillips, B. R. \& Coltice, N. Temperature beneath continents as a function of continental cover and convective wavelength. Journal of Geophysical Research 115, B04408 (2010).

81 Doucet, L. S. et al. Distinct formation history for deep-mantle domains reflected in geochemical differences. Nature Geoscience 13, 511-515 (2020).

82 Doucet, L. S., Li, Z. X., Ernst, R. E., Kirscher, U. \& Gamal El Diean, H. Coupled supercontinent-mantle plume events evidenced by oceanic plume record. Geology, doi:https://doi.org/10.1130/G46754.1 (2019).

83 Anderson, D. L. Hotspots, polar wander, Mesozoic convection and the geoid. Nature 297, 391-393 (1982).

84 Evans, D. A. D. Proposal with a ring of diamonds. Nature 466, 326-327 (2010).

85 Liu, X. \& Zhong, S. The long-wavelength geoid from three-dimensional spherical models of thermal and thermochemical mantle convection. Journal of Geophysical Research: Solid Earth 120, 4572-4596 (2015).

86 Gurnis, M. Large-scale mantle convection and the aggregation and dispersal of supercontinents. Nature 332, 695-699 (1988).

87 Anderson, D. L. Superplumes or supercontinents? Geology 22, 39-42 (1994).

88 Torsvik, T. H. \& Cocks, R. M. Earth history and palaeogeography. (Cambridge University Press, 2016).

89 Berner, R. A. Phanerozoic atmospheric oxygen: New results using the GEOCARBSULF model. American Journal of Science 309, 603-606 (2009).

90 Kump, L. R. The rise of atmospheric oxygen. Nature 451, 277-278 (2008).

91 Mann, P., Gahagan, L. \& Gordon, M. B. in Giant oil and gas fields of the decade 1990-1999 Vol. 78 (ed M.T. Halbouty) 15-105 (AAPG Memoir, 2003).

92 Campbell, I. H. \& Allen, C. M. Formation of supercontinents linked to increases in atmospheric oxygen. Nature Geoscience 1, 554-558 (2008).

93 Condie, K. C. Episodic continental growth and supercontinents: a mantle avalanche connection? Earth and Planatary Science Letters 163, 97-108 (1998).

94 Condie, K. C. The supercontinent cycle: Are there two patterns of cyclicity? Journal of African Earth Sciences 35, 179-183 (2002).

95 Sutton, J. Long-term cycles in the evolution of the continents. Nature 198, 731-735 (1963). 
96 Bradley, D. C. Secular trends in the geologic record and the supercontinent cycle. EarthScience Reviews 108, 16-33 (2011).

97 Li, Z. X. et al. Decoding Earth's rhythm: Modulation of supercontinent cycles by longer superocean episodes. Precambrian Research 323, 1-5 (2019).

98 Zhao, H. Q. et al. New geochronologic and paleomagnetic results from early Neoproterozoic mafic sills and late Mesoproterozoic to early Neoproterozoic successions in the eastern North China Craton, and implications for the reconstruction of Rodinia. Geological Society of America Bulletin 132, 739-766 (2020).

99 Merdith, A. S. et al. A full-plate global reconstruction of the Neoproterozoic. Gondwana Research (2017).

100 Evans, D. A. D. in Ancient Orogens and Modern Analogues Vol. 327 (eds J.B. Murphy, J.D. Keppie, \& A.J. Hynes) 371-404 (Geological Society, London, Special Publications, 2009).

$101 \mathrm{Li}, \mathrm{Z} . \mathrm{X} . \&$ Evans, D. A. D. Late Neoproterozoic $40^{\circ}$ intraplate rotation within Australia allows for a tighter-fitting and longer-lasting Rodinia. Geology 39, 39-42 (2011).

102 Li, Z.-X. et al. Assembly, configuration, and break-up history of Rodinia: A synthesis. Precambrian Research 160, 179-210 (2008).

103 Li, Z. X., Evans, D. A. D. \& Halverson, G. P. Neoproterozoic glaciations in a revised global palaeogeography from the breakup of Rodinia to the assembly of Gondwanaland. Sedimentary Geology 294, 219-232 (2013).

104 Hoffman, P. F. Did the breakout of Laurentia turn Gondwanaland inside-out? Science 252, 1409-1412 (1991).

105 Hoffman, P. F. in Earth Structure: An Introduction to Structural Geology and Tectonics (eds B.A. van der Pluijm \& S. Marshak) 459-464 (McGraw-Hill, 1997).

106 Evans, D. A. D. \& Mitchell, R. N. Assembly and breakup of the core of PaleoproterozoicMesoproterozoic supercontinent Nuna. Geology39, 443-446 (2011).

107 Zhang, S. et al. Pre-Rodinia supercontinent Nuna shaping up: A global synthesis with new paleomagnetic results from North China. Earth and Planatary Science Letters 353354, 145-155 (2012).

108 Kirscher, U. et al. Paleomagnetism of the Hart Dolerite (Kimberley, Western Australia) A two-stage assembly of the supercontinent Nuna? Precambrian Research 329, 170-181 (2019).

109 Mitchell, R. N., Kirscher, U., Kunzmann, M., Liu, Y. \& Cox, G. M. Gulf of Nuna: Astrochronologic correlation of a Mesoproterozoic oceanic euxinic event. Geology 49, 25-29 (2021).

110 Wu, H., Zhang, S., Li, Z.-X., Li, H. \& Dong, J. New paleomagnetic results from the Yangzhuang Formation of the Jixian System, North China, and tectonic implications. Chinese Science Bulletin 50, 1483-1489 (2005).

111 Pisarevsky, S. A., Elming, S.-A., Pesonen, L. J. \& Li, Z.-X. Mesoproterozoic paleogeography: Supercontinent and beyond. Precambrian Research 244, 207-225 (2014).

112 Zhao, G., Cawood, P. A., Wilde, S. A. \& Sun, M. Review of global 2.1-1.8 Ga orogens: implications for a pre-Rodinia supercontinent. Earth-Science Reviews 59, 125-162 (2002).

113 Zhao, G. C., Sun, M., Wilde, S. A. \& Li, S. Z. A Paleo-Mesoproterozoic supercontinent: Assembly, growth and breakup. Earth-Science Reviews 67, 91-123 (2004).

114 Zhao, G., Li, S., Sun, M. \& Wilde, S. A. Assembly, accretion, and break-up of the PalaeoMesoproterozoic Columbia supercontinent: Record in the North China Craton revisited. International Geology Review53, 1331-1356 (2011).

115 Wang, C., Mitchell, R. N., Murphy, J. B., Peng, P. \& Spencer, C. J. The role of megacontinents in the supercontinent cycle. Geology, doi:https://doi.org/10.1130/G47988.1 (2020).

116 Raub, T. D., Kirschvink, J. L. \& Evans, D. in Treatise on Geophysics Vol. 5 565-589 (2007).

117 Ernst, R. E. et al. Long-lived connection between southern Siberia and northern Laurentia in the Proterozoic. Nature Geoscience 9, 464-469 (2016). 
118 Evans, D. A. D., Veselovsky, R. V., Petrov, P. Y., Shatsillo, A. V. \& Pavlov, V. E. Paleomagnetism of Mesoproterozoic margins of the Anabar Shield: A hypothesized billion-year partnership of Siberia and northern Laurentia. Precambrian Research 281, 639-655 (2016).

119 Pisarevsky, S. A., Natapov, L. M., Donskaya, T. V., Gladkochub, D. P. \& Vernikovsky, V. A. Proterozoic Siberia: a promontory of Rodinia. Precambrian Research 160, 66-76 (2008).

120 Cawood, P. A. et al. Deconstructing South China and consequences for reconstructing Nuna and Rodinia. Earth-Science Reviews 204, 103169 (2020).

121 Spencer, C. J., Hawkesworth, C., Cawood, P. A. \& Dhiume, B. Not all supercontinents are created equal: Gondwana-Rodinia case study. Geology 41, 795-798 (2013).

122 Liu, C., Knoll, A. H. \& Hazen, R. M. Geochemical and mineralogical evidence that Rodinian assembly was unique. Nature Communications 8, 1950 (2017).

123 Leach, D. L. et al. Sediment-hosted lead-zinc deposits in Earth history. Economic Geology 105, 593-625 (2010).

124 Hoffman, P. F. et al. Snowball Earth climate dynamics and Cryogenian geologygeobiology. Science Advances 3, e1600983 (2017).

125 Hoffman, P. F., Kaufman, A. J., Halverson, G. P. \& Schrag, D. P. A Neoproterozoic snowball Earth. Science 281, 1342-1346 (1998).

126 Kirschvink, J. L. in The Proterozoic Biosphere: A Multidisciplinary Study (eds J.W. Schopf \& C. Klein) 51-52 (Cambridge Univeristy Press, 1992).

127 Evans, D. A. D. Stratigraphic, geochronological, and paleomagnetic constraints upon the Neoproterozoic climate paradox. American Journal of Science 300, 347-433 (2000).

128 Keller, C. B. et al. Neoproterozoic glacial origin of the Great Unconformity. Proceedings of the National Academy of Sciences 116, 1136-1145 (2019).

129 Mitchell, R. N. et al. Hit or miss: Glacial incisions of snowball Earth. Terra Nova 00, 1-9 (2019).

130 Gernon, T. M., Hincks, T. K., Tyrell, T., Rohling, E. J. \& Palmer, M. R. Snowball Earth ocean chemistry driven by extensive ridge volcanism during Rodinia breakup. Nature Geoscience 9, 242-248 (2016).

131 Bowring, S. A. \& Grotzinger, J. P. Implications of new chronostratigraphy for tectonic evolution of Wopmay orogen, northwest Canadian Shield. American Journal of Science 292, 1-20 (1992).

132 Hoffman, P. F. The origin of Laurentia: Rae craton as the backstop for proto-Laurentian amalgamation by slab suction. Geoscience Canada 41, 313-320 (2014).

133 Pourteau, A. et al. 1.6 Ga crustal thickening along the final Nuna suture. Geology 46, 959962 (2018).

134 Hoffman, P. F. Speculations on Laurentia's first gigayear (2.0 to $1.0 \mathrm{Ga}$ ). Geology 17, 135138 (1989).

135 Li, Z. X. et al. Geochronology of Neoproterozoic syn-rift magmatism in the Yangtze craton, South China and correlations with other continents: evidence for a mantle superplume that broke up Rodinia. Precambrian Research 122, 85-109 (2003).

136 Li, Z. X., Li, X. H., Kinny, P. D. \& Wang, J. The breakup of Rodinia: did it start with a mantle plume beneath South China? Earth and Planetary Science Letters 173, 171-181 (1999).

137 Mitchell, R. N., Hoffman, P. F. \& Evans, D. A. D. Coronation loop resurrected: Oscillatory apparent polar wander of Orosirian (2.05-1.8 Ga) paleomagnewtic poles from Slave craton. Precambrian Research 179, 121-134 (2010).

138 Mitchell, R. N. et al. Sutton hotspot: Resolving Ediacaran-Cambrian tectonics and true polar wander for Laurentia. American Journal of Science 311, 651-663 (2011).

139 Li, Z.-X., Evans, D. A. D. \& Zhang, S. A 90 degrees spin on Rodinia: possible causal links between the Neoproterozoic supercontinent, superplume, true polar wander and lowlatitude glaciation. Earth and Planatary Science Letters 220, 409-421 (2004).

140 Jing, X. et al. A pan-latitudinal Rodinia in the Tonian true polar wander frame. Earth and Planetary Science Letters 530, 115880 (2020). 
141 Swanson-Hysell, N. L. et al. Constraints on Neoproterozoic paleogeography and Paleozoic orogensis from paleomagnetic records of the Bitter Springs Formation, Amadeus Basin, central Australia. American Journal of Science 312, 817-884 (2012).

142 Dhuime, B., Hawkesworth, C. J., Cawood, P. A. \& Storey, C. D. A change in the geodynamics of continental growth 3 billion years ago. Science 334, 1334-1336 (2012).

143 Hawkesworth, C. J., Cawood, P. A. \& Dhiume, B. Rates of generation and growth of the continental crust. Geoscience Frontiers 10, 165-173 (2019).

144 Korenaga, J. Crustal evolution and mantle dynamics through Earth history. Philosophical Transactions A 376, 20170408 (2018).

145 Cox, G. M., Lyons, T. W., Mitchell, R. N., Hasterok, D. \& Gard, M. Linking the rise of atmospheric oxygen to growth in the continental phosphorus inventory. Earth and Planetary Science Letters 489, 28-36 (2018).

146 Blichert-Toft, J. \& Albarde, F. Short-lived chemical heterogeneities in the Archean mantle with implications for mantle convection. Science 263, 1593-1596 (1994).

147 Williams, H., Hoffman, P. F., Lewry, J. F., Monger, J. W. H. \& Rivers, T. Anatomy of North America: thematic geologic portrayls of the continent. Tectonophysics 187, 117-134 (1991).

148 Salminen, J., Oliveira, E., Piispa, E., Smirnov, A. \& Trindade, R. Revisiting the paleomagnetism of the Neoarchean Uauá mafic dyke swarm, Brazil: Implications for Archean supercratons. Precambrian Research 329, 108-123 (2019).

149 Pisarevsky, S. A., De Waele, B., Jones, S., Soderlund, U. \& Ernst, R. E. Paleomagnetism and $\mathrm{U}-\mathrm{Pb}$ age of the $2.4 \mathrm{Ga}$ Erayinia mafic dykes in the south-western Yilgarn, Western Australia: Paleogeographic and geodynamic implications. Precambrian Research 259, 222-231 (2015).

150 Ernst, R. E. \& Bleeker, W. Large igneous provinces (LIPs), giant dyke swarms, and mantle plumes: significance for breakup events within Canada from 2.5 Ga to present. Canadian Journal of Earth Sciences 47, 695-739 (2010).

151 Bleeker, W. \& Ernst, R. E. in Dyke Swarms - Time Markers of Crustal Evolution (eds E. Hanski, S. Mertanen, T. Ramo, \& J. I. Vuollo) 3-26 (Taylor \& Francis Group, 2006).

152 Bleeker, W. The late Archean record: a puzzle in ca. 35 pieces. Lithos 71, 99-134 (2003).

153 Windley, B. F. Crustal development in the Precambrian. Philosophical Transactions of the Royal Society A 273, 321-341 (1973).

154 Cawood, P. et al. Geological archive of the onset of plate tectonics. Philosophical Transactions $A$ (2018).

155 Gumsley, A. P. et al. Timing and tempo of the Great Oxidation Event. Proceedings of the National Academy of Sciences 114, 1811-1816 (2017).

156 Roscoe, S. M. \& Card, K. D. The reappearance of the Huronian in Wyoming: rifting and drifting of anceint continents. Canadian Journal of Earth Sciences 30, 2475-2480 (1993).

157 Kilian, T. M., Bleeker, W., Chamberlain, K. R., Evans, D. A. D. \& Cousens, B. L. in Supercontinent Cycles Through Earth History Vol. 424 (eds Z.-X. Li, D.A.D. Evans, \& J.B. Murphy) 15-45 (Geological Society, London, Special Publications, 2016).

158 Liu, Y. et al. Archean geodynamics: Ephemeral supercontinents or long-lived supercratons. Geology, doi:DOI:10.1130/G48575.1 (2021).

159 De Kock, M. O., Evans, D. A. D. \& Beukes, N. J. Validating the existence of Vaalbara in the Neoarchean. Precambrian Research 174, 145-154 (2009).

160 Evans, M. E. \& Muxworthy, A. R. Vaalbara palaeomagnetism. Canadian Journal of Earth Sciences 56, 912-916 (2019).

161 de Wit, M. J. et al. Formation of an Archaean continent. Nature 357, 553-562 (1992).

162 van Hunen, J. \& Moyen, J.-F. Archean subduction: Fact or fiction? Annual Review of Earth and Planetary Sciences 40, 195-219 (2012).

163 Moyen, J.-F. \& Laurent, O. Archaean tectonic systems: A view from igneous rocks. Lithos 302-303, 99-125 (2018). 
164 Rolf, T., Coltice, N. \& Tackley, P. J. Linking continental drift, plate tectonics and the thermal state of the Earth's mantle. Earth and Planatary Science Letters 351-352, 134146 (2012).

165 Zhang, N., Zhong, S. J. \& McNamara, A. K. Supercontinent formation from stochastic collision and mantle convection models. Gondwana Research 15, 267-275 (2009).

166 Yoshida, M. Mantle convection with longest-wavelength thermal heterogeneity in a 3-D spherical model: Degree one or two? Geophysical Research Letters 35, L23302 (2008).

167 Grigne, C., Labrosse, S. \& Tackley, P. J. Convective heat transfer as a function of wavelength: Implications for the cooling of the Earth. Journal of Geophysical Research 110, B03409 (2005).

168 Lenardic, A., Richards, M. A. \& Busse, F. H. Depth-dependent rheology and the horizontal length scale of mantle convection. Journal of Geophysical Research 111, B07404 (2006).

169 Biggin, A. J. et al. Palaeomagnetic field intensity variations suggest Mesoproterozoic inner-core nucleation. Nature 526, 245-248 (2015).

170 Bono, R. K., Tarduno, J. A., Nimmo, F. \& Cottrell, R. D. Young inner core inferred from Ediacaran ultra-low geomagnetic field intensity. Nature Geoscience 12, 143-147 (2019).

171 Bunge, H. P., RIchards, M. A. \& Baumgardner, J. R. Effect of depth-dependent viscosity on the planform of mantle convection. Nature 379, 436-438 (1996).

172 Evans, D. A. Pannotia under prosecution. Geological Society, London, Special Publications, doi:https://doi.org/10.1144/SP503-2020-182 (2020).

173 Murphy, J. B. et al. Pannotia: in defense of its existence and geodynamic significance. Geological Society, London, Special Publications 503, doi:https://doi.org/10.1144/SP503-2020-96 (2020).

174 Yoshida, M. Formation of a future supercontinent through plate motion-driven flow coupled with mantle downwelling flow. Geology 44, 755-758 (2016).

175 Yoshida, M. \& Santosh, M. Future supercontinent assembled in the northern hemisphere. Terra Nova 23, 333-338 (2011).

176 Replumaz, A., Karasn, H., van der Hilst, R., Besse, J. \& Tapponnier, P. 4-D evolution of SE Asia's mantle from geological reconstructions and seismic tomography. Earth and Planatary Science Letters 221, 103-115 (2004).

177 Coltice, N., Phillips, B. R., Bertrand, H., Ricard, Y. \& Rey, P. Global warming of the mantle at the origin of flood basalts over supercontinents. Geology35, 391-394 (2007).

178 Müller, R. D., Sdrolias, M., Gaina, C. \& Roest, W. R. Age, spreading rates, and spreading asymmetry of the world's ocean crust. Geochemistry Geophysics Geosystems 9, Q04006 (2008).

179 Zhang, N., Dang, Z., Huang, C. \& Li, Z. X. The dominant driving force for supercontinent breakup: Plume push or subduction retreat? Geoscience Frontiers 9, 997-1007 (2018).

180 Buiter, S. J. H. \& Torsvik, T. H. A review of Wilson Cycle plate margins: A role for mantle plumes in continental break-up along sutures? Gondwana Research 26, 627-653 (2014).

181 Dang, Z. et al. Weak orogenic lithosphere guides the pattern of plume-triggered supercontinent break-up. Nature Communications Earth \& Environment 1, 51 (2020).

182 Brune, S., Popov, A. A. \& Sobolev, S. V. Quantifying the thermo-mechanical impact of plume arrival on continental break-up. Tectonophysics 604, 51-59 (2013).

183 Koptev, A., Calais, E., Burov, E., Leroy, S. \& Gerya, T. Dual continental rift systems generated by plume-lithosphere interaction. Nature Geoscience 8, 388-392 (2015).

184 Bercovici, D. \& Long, M. D. Slab rollback instability and supercontinent dispersal. Geophysical Research Letters 41, 6659-6666 (2014).

185 Huang, C. et al. Modeling the Inception of Supercontinent Breakup: Stress State and the Importance of Orogens. Geochemistry, Geophysics, Geosystems 20, 4830-4848 (2019).

186 Hartnady, C. J. H. About turn for supercontinents. Nature 352, 476-478 (1991).

187 Hartnady, C. J. H. Supercontinents and geotectonic megacycles. Precambrian Research Unit Information Circular No. 1 Part 2, 6-16 (1991). 
188 Veevers, J. J., Walter, M. R. \& Scheibner, E. Neoproterozoic tectonics of AustraliaAntarctica and Laurentia and the 560 Ma birth of the Pacific Ocean reflect the 400 m.y. Pangean supercycle. Journal of Geology 105, 225-242 (1997).

189 Silver, P. G. \& Behn, M. D. Intermittent Plate Tectonics? Science 319, 85-88 (2008).

190 Murphy, J. B. \& Nance, R. D. Do supercontinents introvert or extrovert? Sm-Nd isotopic evidence. Geology 31, 873-876 (2003).

191 Collins, W. J., Belousova, E. A., Kemp, A. I. S. \& Murphy, J. B. Two contrasting Phanerozoic orogenic systems revealed by hafnium isotope data. Nature Geoscience 4, 333-337 (2011).

192 Murphy, J. B. \& Nance, R. D. Speculations on the mechanisms for the formation and breakup of supercontinents. Geoscience Frontiers 4, 185-194 (2013).

193 Bradley, D. C. Passive margins through earth history. Earth-Science Reviews 91, 1-26 (2008).

194 Condie, K. C. \& Aster, R. C. Episodic zircon age spectra of orogenic granitoids: the supercontinent connection and continental growth. Precambrian Research 180, 227-236 (2010).

195 El Dien, H. G., Doucet, L. S. \& Li, Z. X. Global geochemical fingerprinting of plume intensity suggests coupling with the supercontinent cycle. Nature Communications 10, 5270 (2019).

196 Spencer, C. J., Roberts, N. M. W. \& Santosh, M. Growth, destruction, and preservation of Earth's continental crust. Earth-Science Reviews 172, 87-106 (2017).

197 Valley, J. W. e. a. 4.4 billion years of crustal maturation: Oxygen isotope ratios of magmetic zircon. Contributions to Mineralogy and Petrology 150, 561-580 (2005).

198 Spencer, C. J. et al. Paleoproterozoic increase in zircon d180 driven by rapid emergence of continental crust. Geochem Cosmochem Acta 257, 16-25 (2019).

199 Jensen, G. Closed-form estimation of multiple change-point models. PeerJ PrePrints, doi:https://doi.org/10.7287/peerj.preprints.90v3 (2013).

200 Barnosky, A. D. et al. Approaching a state shift in Earth's biosphere. Nature 486, 52-58 (2012).

201 Lenardic, A. The diversity of tectonic modes and thoughts about transitions between them. Philosophical Transactions of the Royal Society A 376, 20170416 (2018).

202 Bauer, A. M. et al. Hafnium isotopes in zircons document the gradual onset of mobile-lid tectonics. Geochemical Perspectives Letters 14, 1-6 (2020).

203 Spencer, C. J., Murphy, J. B., Kirkland, C. L., Liu, Y. \& Mitchell, R. N. A Palaeoproterozoic tectono-magmatic lull as potential trigger for the supercontinent cycle. Nature Geoscience 11, 97-101 (2018).

204 McNamara, A. K. \& Zhong, S. Thermochemical structures beneath Africa and the Pacific Ocean. Nature 437, 1136-1139 (2005).

205 Davaille, A. \& Romanowicz, B. Deflating the LLSVPs: Bundles of mantle thermochemical plumes rather than thick stagnant "piles". Tectonics 39, e2020TC006265 (2020).

206 Labrosse, S., Hernlund, J. W. \& Coltice, N. A crystallizing dense magma ocean at the base of the Earth's mantle. Nature 450, 866-869 (2007).

207 Boyet, M. \& Carlson, R. W. 142Nd evidence for early (4.53 Ga) global differentiation of the silicate Earth. Science 309, 576-581 (2005).

208 Upadhyay, D., Scherer, E. E. \& Mezger, K. 142Nd evidence for an enriched Hadean reservoir in cratonic roots. Nature 459, 1118-1121 (2009).

209 Roth, A. S. G., Scherer, E. E., Maden, C., Mezger, K. \& Bourdon, B. Revisiting the $142 \mathrm{Nd}$ deficits in the 1.48 Ga Khariar alkaline rocks, India. Chemical Geology 386, 238-248 (2014).

210 Rizo, H. et al. Preservation of Earth-forming events in the tungsten isotopic composition of modern flood basalts. Science 352, 809-812 (2016).

211 Mundl, A. et al. Tungsten-182 heterogeneity in modern ocean island basalts. Science 356, 66-69 (2017). 
212 Ballmer, M. D., Houser, C., Hernlund, J. W., Wentzcovitch, R. M. \& Hirose, K. Persistence of strong silica-enriched domains in the Earth's lower mantle. Nature Geoscience 10, 236240 (2017).

213 Horan, M. F. et al. Tracking Hadean processes in modern basalts with 142-Neodymium. Earth and Planatary Science Letters 484, 184-191 (2018).

214 Rizo, H., Boyet, M., Blichert-Toft, J. \& Rosing, M. T. Early mantle dynamics inferred from $142 \mathrm{Nd}$ variations in Archean rocks from southwest Greenland. Earth and Planatary Science Letters 377-378, 324-335 (2013).

215 Hyung, E. \& Jacobsen, S. B. The 142Nd/144Nd variations in mantle-derived rocks provide constraints on the stirring rate of the mantle from the Hadean to the present. Proceedings of the National Academy of Sciences 117, 14738-14744 (2020).

216 Lyons, T. W., Reinhard, C. T. \& Planavsky, N. J. The rise of oxygen in Earth's early ocean and atmosphere. Nature 506, 307-315 (2014).

217 Bindeman, I. N. et al. Rapid emergence of subarial landmasses and onset of a modern hydrologic cycle 2.5 billion years ago. Nature 557, 545-548 (2018).

218 Nicoli, G., Moyen, J.-F. \& Stevens, G. Diversity of burial rates in convergent settings decreased as Earth aged. Scientific Reports 6, 26359 (2016).

219 Knoll, A. H. \& Nowak, M. A. The timetable of evolution. Science Advances 3, e1603076 (2017).

220 Hazen, R. M. et al. Mineral evolution. American Mineralogist 93, 1693-1720 (2008).

221 Lepot, K. et al. Iron minerals with specific microfossil morphospecies of the $1.88 \mathrm{Ga}$ Gunflint Formation. Nature Communications 8 (2017).

222 Eriksson, K. A. \& Simpson, E. L. Controls on spatial and temporal distribution of Precambrian eolianites. Sedimentary Geology 120, 275-294 (1998).

223 Rodriguez-Lopez, J. P., Clemmensen, L. B., Lancaster, N., Mountney, N. P. \& Veiga, G. D. Archean to recent aeolian sand systems and their sedimentary record: Current understanding and future prospects. Sedimentology 61, 1487-1534 (2014).

224 Merdith, A. S., Williams, S. E., Brune, S., Collins, A. S. \& Müller, R. D. Rift and plate boundary evolution across two supercontinent cycles. Global and Planetary Change 173, 1-14 (2019).

225 Zhang, N. \& Zhong, S. Heat fluxes at the Earth's surface and core-mantle boundary since Pangea formation and their implications for the geomagnetic superchrons. Earth and Planatary Science Letters 306, 205-216 (2011).

226 Zhang, S.-H., Zhao, Y., Li, X.-H., Ernst, R. E. \& Yang, Z.-Y. The 1.33-1.30 Ga Yanliao large igenous province in the North China Craton: Implications for reconstruction of the Nuna (Columbia) supercontinent, and specifically with the North Australian Craton. Earth and Planatary Science Letters 465, 112-125 (2017).

227 Domeier, M. \& Torsvik, T. H. Full-plate modelling in pre-Jurassic time. Geological Magazine 152, 261-280 (2019).

228 Rogers, J. J. W. \& Santosh, M. Configuration of Columbia, a Mesoproterozoic supercontinent. Gondwana Research 5, 5-22 (2002).

229 Evans, D. A. D. Proterozoic low orbital obliquity and axial-dipolar geomagnetic field from evaporite palaeolatitudes. Nature 444, 51-55 (2006).

230 Panzik, J. \& Evans, D. A. Assessing the GAD hypothesis with paleomagnetic data from large dike swarms. Earth and Planetary Science Letters 406, 134-141 (2014).

231 Evans, D. A. D. \& Pisarevsky, S. Plate tectonics on early Earth? Weighing the paleomagnetic evidence. 249-263 (2008).

232 Bercovici, D., Tackley, P. J. \& Ricard, Y. in Treatise in Geophysics, 2 ed., vol. 7, Mantle Dynamics (ed editor in chief D. Bercovici editor; G. Schubert) (Elsevier, 2015).

233 Korenaga, J. Urey ratio and the structure and evolution of Earth's mantle. Reviews of Geophysics 46, RG2007 (2008).

234 Steinberger, B. \& Torsvik, T. H. Toward an explanation for the present and past locations of the poles. Geochemistry, Geophysics, Geosystems 11, Q06W06 (2010). 
235 Steinberger, B., Schmeling, H. \& Marquart, G. Large-scale lithospheric stress field and topography induced by global mantle circulation. Earth and Planetary Science Letters 186, 75-91 (2001).

236 Herzberg, C., Condie, K. C. \& Korenaga, J. Thermal history of the Earth and its petrological expression. Earth and Planatary Science Letters 292, 79-88 (2010).

237 Keller, C. B. \& Schoene, B. Statistical geochemistry reveals disruption in secular lithospheric evolution about 2.5 Gyr ago. Nature 485, 490-493 (2012).

238 McLennan, S. M. in Geochemistry and Mineralogy of Rare Earth Elements: Reviews in Mineralogy Vol. 21 (eds B.R. Lipin \& G.A. McKay) 169-200 (1989).

239 Johnson, T. E., Brown, M., Kaus, B. J. P. \& VanTongeren, J. A. Delamination and recycling of Archaean crust caused by gravitational instabilities. Nature Geoscience 7, 47-52 (2013).

240 Johnson, T. E., Brown, M., Gardiner, N. J., Kirkland, C. L. \& Smithies, R. H. Earth's first stable continents did not form by subduction. Nature 543, 239-242 (2017).

241 Shirey, S. B. \& Richardson, S. H. Start of the Wilson cycle at 3 Ga shown by diamonds from subcontinental mantle. Science 333, 434-436 (2011).

\section{Acknowledgements}

Support for this work came from the National Natural Science Foundation of China (grants 41888101 and 41890833 to R.N.M. and 41976066 to N.Z.), the Key Research Program of the Institute of Geology and Geophysics, Chinese Academy of Sciences (grant IGGCAS-201905 to R.N.M.), the Centre of Excellence project 223272 through the Research Council of Norway and the innovation pool of the Helmholtz Association through the "Advanced Earth System Modelling Capacity (ESM)" activity (B.S.), and the Australian Research Council (grant FL150100133 to Z.X.L.). This is a contribution to International Geoscience Programme (IGCP) 648.

\section{Author contributions}

R.N.M. conceived the study. N.Z. and B.S. conducted numerical modeling. J.S., Y.L., and Z.X.L. made palaeogeographic reconstructions. C.S. conducted geochemical analyses. J.B.M. coordinated the presentation of the various sections. All authors contributed to the manuscript preparation, interpretation, discussion, and writing, led by R.N.M.

\section{Competing interests}

The authors declare no competing interests.

\section{Peer review information}

Nature Reviews Earth \& Environment thanks [Referee\#1 name], [Referee\#2 name] and the other, anonymous, reviewer(s) for their contribution to the peer review of this work.

\section{Publisher's note}

Springer Nature remains neutral with regard to jurisdictional claims in published maps and institutional affiliations.

\section{Supplementary information}

Supplementary information is available for this paper at https://doi.org/10.1038/s415XX-XXXXXXX-X

\section{Key points}

- The supercontinent cycle is an outcome of plate tectonics as a self-organizing system, where a supercontinent is both an effect and a cause of mantle convection, thus creating a feedback loop. 
- According to palaeogeography, three supercontinent cycles of assembly and breakup have occurred over the past 2 billion years (Gyr).

- Before 2 Gyr ago, the occurrence of an older supercontinent is uncertain, and possibly only smaller and separated landmasses existed.

- Geochemical proxies indicate secular change suggesting tectonic evolution from non-cyclic to cyclic changes occurring ca. 2 Gyr ago with the appearance of supercontinents.

- For a better understanding of supercontinent dynamics, it is necessary to connect mantle convection and plate tectonics into one theory.

- Both top-down (lithospheric) and bottom-up (mantle) tectonics control supercontinent dynamics and it is critical to understand the coupling between them. 
Figures

Fig. 1. I Supercontinents through time. Timeline of supercontinent cycles with palaeogeographic reconstructions at $200 \mathrm{Ma}, 800 \mathrm{Ma}, 1300 \mathrm{Ma}$ and $2450 \mathrm{Ma}$. Pangaea, Rodinia and Columbia are supercontinents, whereas Superia is a hypothesized supercraton and might not have included all or even most cratons globally (that is, an Archaean supercontinent). Inset shows Superia at a larger scale, with the geometry of coeval dyke swarms and layered intrusions (with ages) and cover sequences. Dashed lines project dykes and intrusions to plume centres (stars). Plata, Rio de la Plata craton. Euler rotation parameters for palaeogeographic reconstructions are provided in Supplementary Table 2.

Fig. 2 | Supercontinent Pangaea and mantle structure. The lower mantle exhibits two large low-velocity shear-wave provinces (LLSVPs, red) with higher velocities (blue) in between. This pattern is typical of long-wavelength degree-two structure, which is suggested to have persisted since at least $200 \mathrm{Ma}^{47-53}$. From that structure, whole-mantle convection is inferred with upwellings above LLSVPs that are separated by downwelling that reflects subduction of oceanic lithosphere and with lower mantle flow towards LLSVPs, but with upper mantle flow predominantly away from LLSVPs. Central meridian is $020^{\circ} \mathrm{E}$. Tomography is for $2800 \mathrm{~km}$ depth. Plate reconstruction at $200 \mathrm{Ma}$ from REFS $^{60,78}$ is in a true polar wander (TPW) reference frame. Adapted with permission from REF. ${ }^{78}$.

Fig. 3. | Numerical modelling of long-wavelength mantle convection. Supercontinentinduced long-wavelength mantle convection influences core-mantle heat flux. Modes of mantle convection associated with supercontinent geodynamics: al Random flow pattern, perhaps representative of the Archaean, before the supercontinent cycle began. b| Degree 1 flow that promotes supercontinent assembly over the superdownwelling. $\mathrm{c}$ | Degree 2 mantle flow during supercontinent breakup with antipodal upwelling zones (yellow) bisected by a girdle of downwelling. Earth's core is red, mantle downwelling is blue (associated with tectonic subduction), and mantle upwelling is yellow (associated with tectonic rifting). $\mathrm{d}$ | Core-mantle boundary heat flow simulation during a transition from a random to $\mathrm{b}$ degree 1 mantle flow. el Core-mantle boundary heat flow simulation during a transition from $b$ degree 1 mantle flow to c degree 2 mantle flow. In both $\mathrm{d}$ and e, heat flux is recorded after the initial mantle overturn. For panels a-d simulations updated from those of REF. ${ }^{74}$. For panel e, simulations updated from REF. ${ }^{225}$.

Fig. 4. | Supercontinent time series. Oxygen isotopes $\left(\delta^{18} 0\right)$ of zircon can be used as a geochemical proxy of the supercontinent cycle through time. Lower average isotopic values indicate more mantle-derived magmatism (for example, during tectonic rifting) and higher values indicate more crustal reworking (for example, during subduction). Note both higher overall values and cycles initiate in the $\delta^{18} 0$ data after 2.5 Ga. Note cycles correspond to higher $\delta^{18} 0$ during assembly and lower $\delta^{18} 0$ during breakup phases of each of the 3 supercontinent cycles (Pangaea, Rodinia and Columbia). Average isotopic values (solid line) with $1 \sigma$ uncertainties (dashed lines) were defined using a freely available statistical change-point analysis ${ }^{199}$ and suggest a state shift to cyclic variations ca. $2.5 \mathrm{Ga}$ (see also Box 3). Plot has been truncated at $30 \mathrm{Ma}$ because of the sampling of anomalous $\delta^{18} \mathrm{O}$ values in neotectonic settings. Raw data are from REF. ${ }^{196}$. 


\section{Boxes}

[B1] Reconstructing supercontinents. Diverse types of evidence are used to reconstruct Precambrian (pre-Pangaean) supercontinents ${ }^{10,227}$ including: palaeomagnetism, orogens of the same age and metamorphic style, the distribution of passive margins surrounding central blocks, geological piercing points (for example, the geometry of large radiating dyke swarms), detrital zircon provenance, and more. As continents must collide during supercontinent assembly, identifying an orogenic suture with coeval collisional orogens on the margins of two continents provides the most obvious test that two continents were neighbours in a supercontinent ${ }^{31,102,112,113,228}$. Then, during supercontinent breakup, continents should share ages of rift-related magmatism prior to passive margin development ${ }^{102,106,113}$.

Palaeomagnetism is the most strictly quantitative method used and is therefore often considered a definitive test of any putative palaeogeographic reconstruction. Palaeomagnetism measures the apparent polar wander (APW; see Box Figure) of a continent with respect to the North Pole between two successive time steps. If continents were part of a supercontinent, then they should share the same APW path for the period of time that they were connected. During supercontinent assembly, APW paths should merge and during breakup, APW paths should diverge.

During the stable tenure of a supercontinent, APW paths of different continents can be superimposed to establish their relative configuration. This method would approximately work even if strong octupole and/or quadrupole components to the magnetic field existed at any time; nonetheless, palaeolatitudes of evaporites ${ }^{229}$ and large mafic dyke swarms ${ }^{230}$ appear to suggest the validity of the geocentric axial dipole (GAD) throughout Proterozoic time. Although palaeomagnetic poles are sufficiently available for APW path comparisons for supercontinents Rodinia and Columbia $100,106,107$, too few poles are as yet available from Archaean cratons, thus palaeogeography across the ArchaeanProterozoic boundary relies predominantly on the geometry of coeval mafic dyke swarms. Box Figure adapted with permission from REF 231.

[B2] Top-down versus bottom-up geodynamics. Geodynamics is controlled by both topdown (lithospheric) and bottom-up (mantle) tectonics. Convection is necessarily massbalanced (what goes down must be balanced by what comes up), but abundant evidence on Earth for convective asymmetry (either dominance of top-down or bottom-up tectonics) exists ${ }^{232}$. With only bottom heating, Cartesian geometry, without secular cooling and with constant viscosity, Rayleigh-Bénard convection should be symmetric. However, complications including internal heating and temperature-dependent viscosity lead to convective asymmetry.

Basal heating from the core represents only about a quarter of the heat released from the mantle, indicating the importance of internal heating and secular cooling233. Both primordial fossil heat and the decay of radiogenic elements contribute to the heat flow out of the mantle. The average mantle temperature is higher than it would be if there was no internal heating and secular cooling, so with these additional heat sources the 
temperature drop is larger (smaller) across the upper (lower) thermal boundaries of the mantle, respectively, than without them. Temperature-dependent viscosity creates a stiff upper thermal boundary layer (in other words, the lithosphere is stiffer than the convecting mantle), reinforcing convective asymmetry.

In plate tectonics, mantle downwellings primarily occur as subducting slabs. Analogue and numerical modelling indicate that the development of large-wavelength convection (as consistent with supercontinent formation) is dominated by strong downwellings (slabs) and relatively weak focussed upwellings (plumes) ${ }^{232}$ plus a diffuse upward return flow to balance mass flux. The superposed stress contributions from top-down (related to flow caused by subducted slabs) and bottom-up (related to upwelling flow above the LLSVPs) components are roughly equal and constructively add up (Box Figure). Thin dark green lines indicate direction of maximum compressive stress. Thick black lines separate regions with principal stresses both positive, with different sign, and both negative. Stresses imposed on lithosphere from mantle flow ${ }^{234}$, computed as in REF. ${ }^{235}$, with palaeogeography at $140 \mathrm{Ma}^{45}$.

[B3] Secular change and the supercontinent state. There is now broad consensus in Earth Science that the planet has cooled over billions of years of mantle convective heat loss 236,237 . Mafic rocks, for example, exhibit a reduction in Ni content through time, which is most likely resulted from less melting of olivine during mantle cooling (Box Figure 3). This secular change in the thermodynamics of the mantle is also thought to be broadly be linked to the evolution of plate tectonics through time ${ }^{26}$. Felsic rocks, for example, exhibit an increase in the $\mathrm{Eu}^{*}$ anomaly ${ }^{238}$, which can be interpreted as an increasing subduction signature since 2.5 Ga (Box Figure 3).

During the Archaean, most of the crust was comprised of tonalite-trondhjemitegranodiorite (TTG) rocks, which could be formed by drip tectonics ${ }^{239}$ (that is, delamination or episodic removal of the lithosphere into the convecting mantle ) in the absence of plate tectonics ${ }^{240}$. Although early evidence of plate tectonics exists ${ }^{241}$, it could have been relatively localized, and evidence of a global plate network is not found until arguably $2 \mathrm{Ga}^{23}$. Strikingly, but perhaps not surprisingly, the three relatively wellestablished supercontinents occur after the global plate network was established.

Plate tectonics is convectively more efficient in cooling the mantle than stagnant- or sluggish-lid convection ${ }^{201}$ (that is, a single-plate regime or one in between tectonic and stagnant-lid end-members, respectively), so the proliferation of plate tectonics might have accelerated secular cooling. Furthermore, as plate tectonics became a global phenomenon and allowed for supercontinent formation ${ }^{23}$, large supercontinents likely led to long-wavelength mantle convection. Long-wavelength mantle convection is convectively more efficient in transferring heat than smaller cells, with degree 2 flow representing a heat flow maximum ${ }^{168}$, thus further expediting planetary cooling. Secular trends in igneous rock geochemistry correlate with the transition from ancient supercratons to modern supercontinents (Box Figure). The 3 supercontinents since 2 Ga are thus arguably a manifestation of this secular change. The apparent sharpness of the state shift is likely affected by its temporal coincidence with the onset of cyclicity at the start of the supercontinent cycle. 


\section{Glossary}

Apparent polar wander (APW)

Palaeomagnetically measured motion of a continent relative to Earth's time-averaged magnetic pole, and results from a combination of both plate motion and true polar wander.

\section{Continental freeboard}

Mean height of the continental crust relative to mean sea level; also referred to as continental emergence when positive in sign.

\section{Degree 1 mantle flow}

One hemisphere of mantle upwelling and one hemisphere of mantle downwelling.

\section{Degree 2 mantle flow}

Two antipodal mantle upwellings bisected by a meridional girdle of mantle downwelling as the most likely degree 2 configuration for Earth's mantle.

\section{Extroversion}

Model of supercontinent formation by closure of the external (Pacific-like) ocean.

\section{Geocentric axial dipole (GAD)}

Earth's magnetic field is dominated by a dipole at the surface that aligns with the spin axis when averaged over 1-10 thousand years.

\section{Geologic piercing points}

Geologic correlations used to test palaeogeographic reconstructions including orogenic sutures, conjugate rift margins, and magmatic intrusions and dyke swarms

\section{Introversion}

Model of supercontinent formation by closure of the internal (Atlantic -like) ocean

\section{Large igneous provinces (LIPs)}

Extremely large ( $>10^{5} \mathrm{~km}^{2}$ areal extent, $>10^{5} \mathrm{~km}^{3}$ volume) magmatic events of intrusives (sills, dikes) and extrusives (lava flows, tephras) often attributed to mantle plumes.

\section{Large low shear-wave velocity provinces (LLSVPs)}

Two low seismic velocity structures in the lower mantle occupying $\sim 8 \%$ and $\sim 9 \%$ of the mantle by volume and mass, respectively, and covering $1 / 5$ of the core-mantle boundary.

\section{Magmatic barcodes}

Record of short-lived magmatic events of a continent or craton that can be compared to those of different fragments to test ancient palaeogeographic reconstructions. 
Buoyant hot mantle material that rises from the core-mantle boundary owing to basal heating of the mantle by the core.

\section{Megacontinent}

Geodynamic precursor to supercontinent formation that is large ( $\sim 70 \%$ the size of its supercontinent) and early (assembly $\sim 200$ Myr before supercontinent amalgamation).

\section{Orthoversion}

Model of supercontinent formation by closure of orthogonal seas (Arctic, Caribbean, and Scotia seas and Indian Ocean) $\sim 90^{\circ}$ away from the centre of the previous supercontinent.

\section{Palaeomagnetism}

Study of rocks containing magnetic minerals that preserve the orientation of the magnetic field and constrain the position of the continent with respect to the North Pole at that age.

\section{Subduction girdle}

Circum-supercontinent subduction coupled with degree 2 mantle downwelling, for example, the present-day 'ring of fire' of circum-Pacific subduction zones.

\section{Supercratons}

Assembly of Archaean cratons, where the landmasses were likely in small and segregated clusters which form an alternative hypothesis to an Archaean supercontinent.

\section{True polar wander (TPW)}

Rotation of solid Earth (mantle and crust) about the liquid outer core to align Earth's maximum moment of inertia with the spin axis; also known as planetary reorientation. 
Fig 1

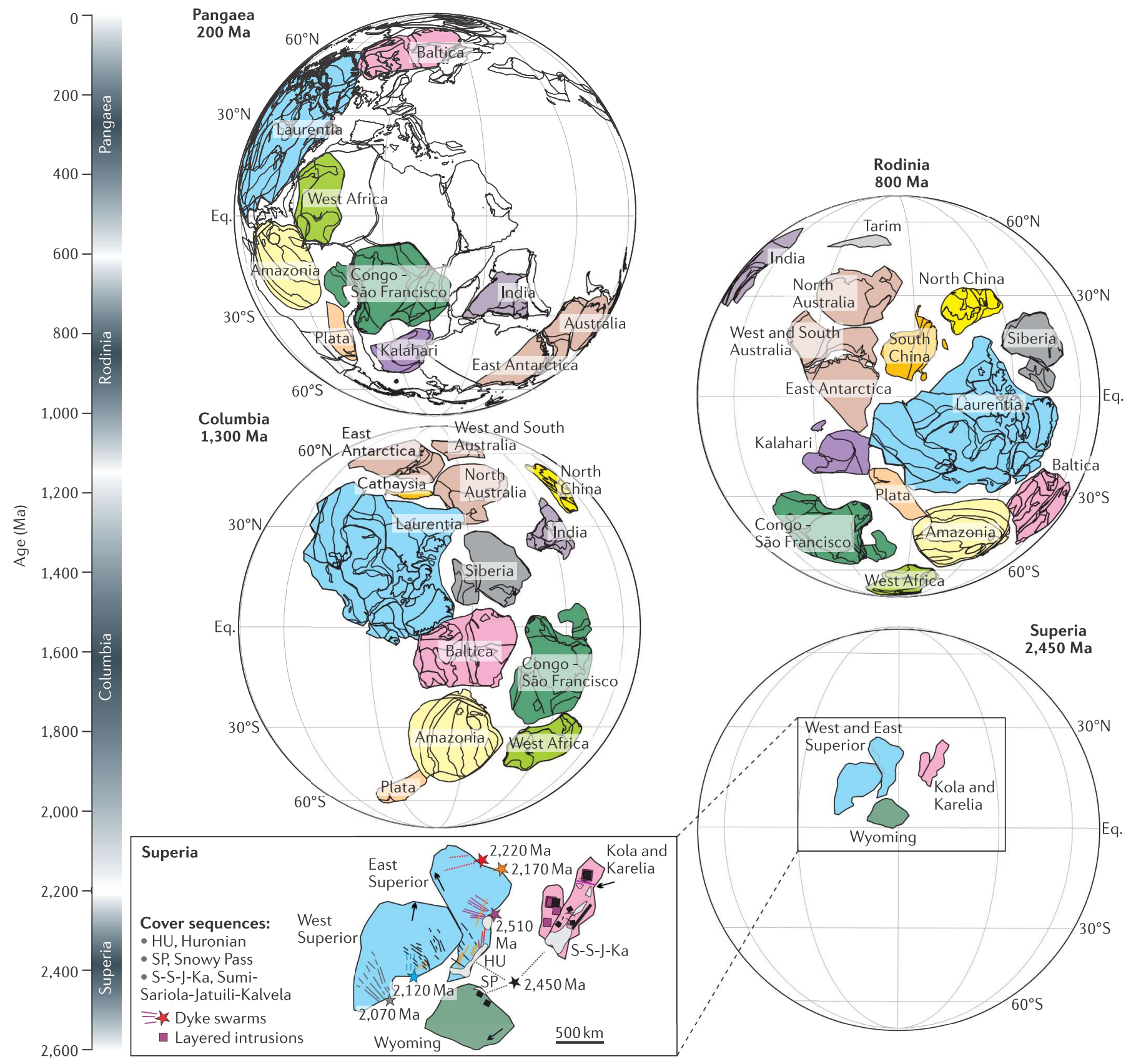


Fig 2

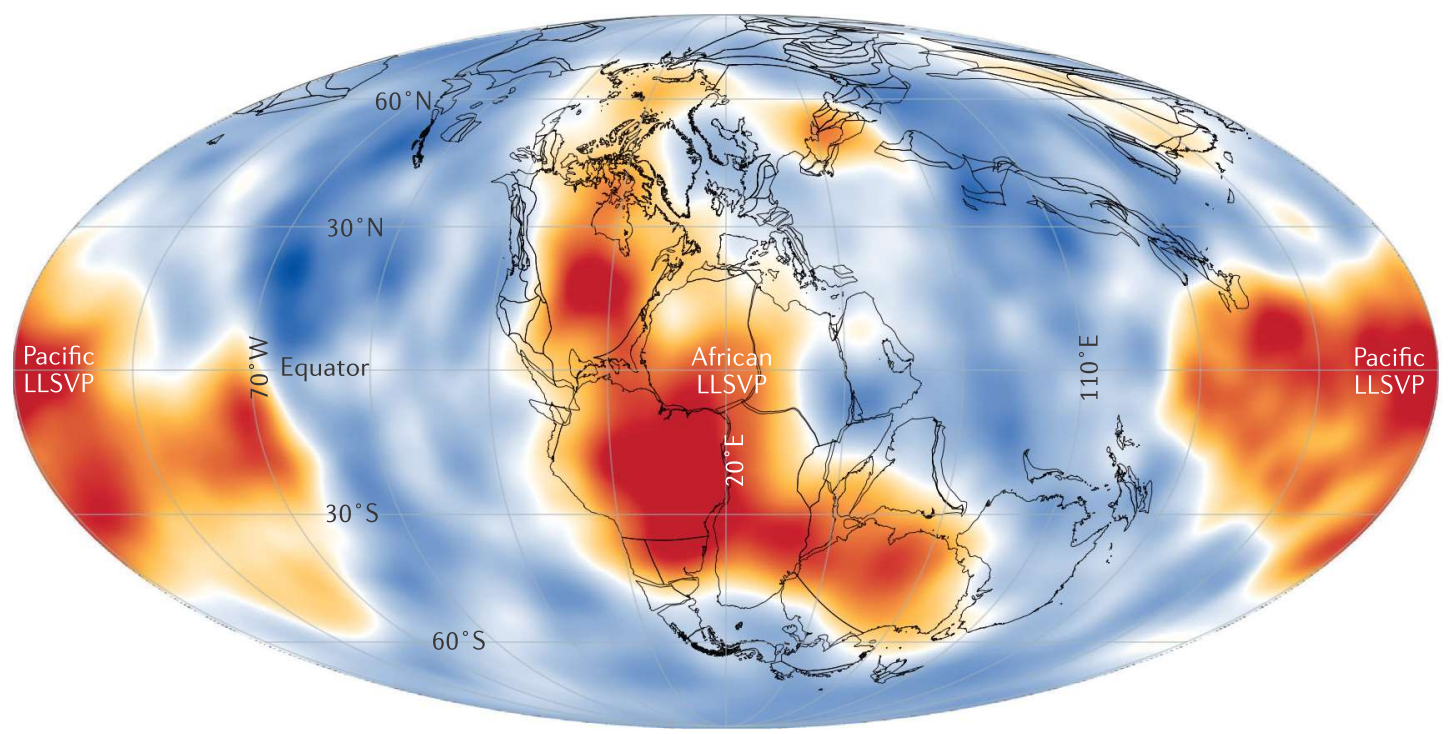

Fig 3
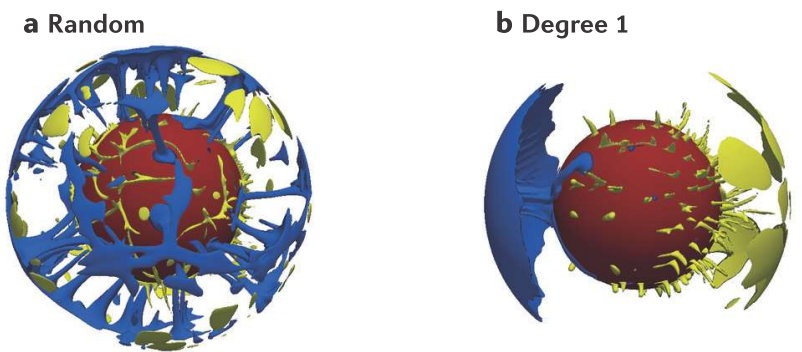

c Degree 2
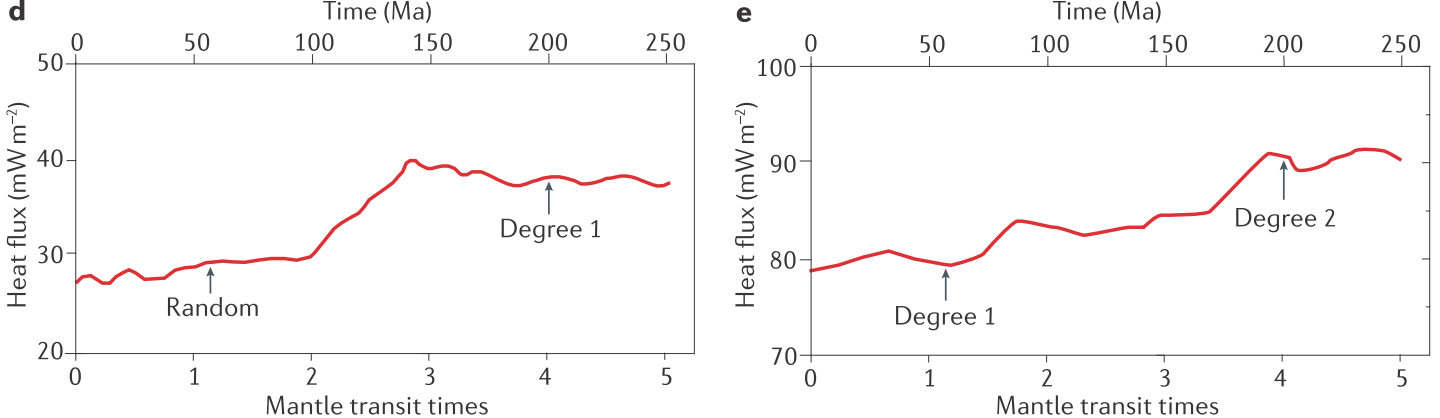
Fig 4

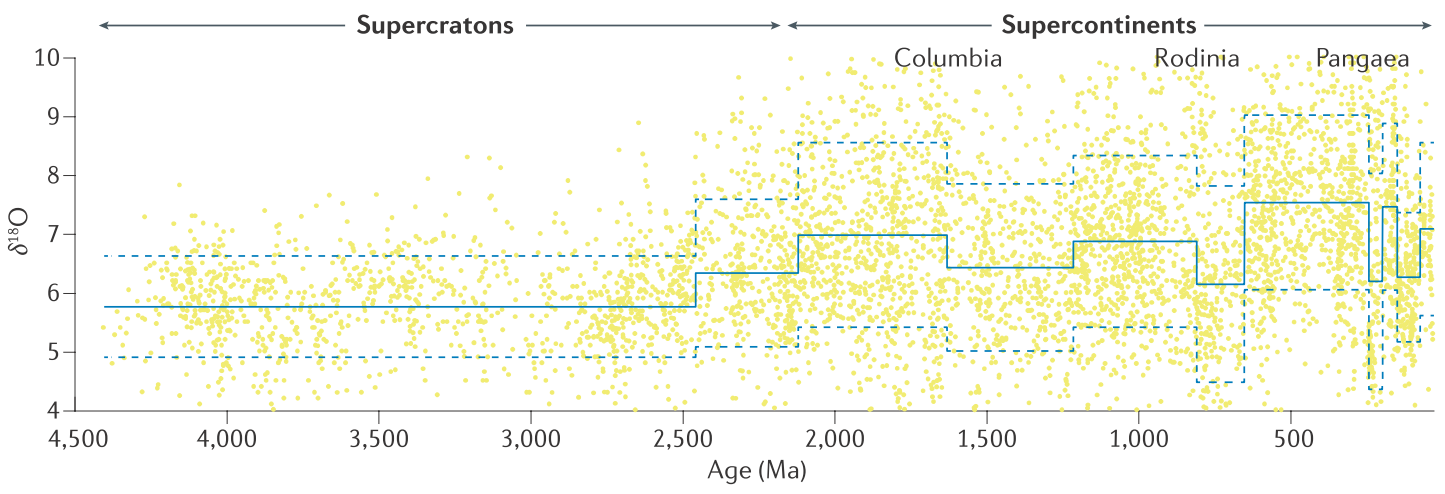

Box 1

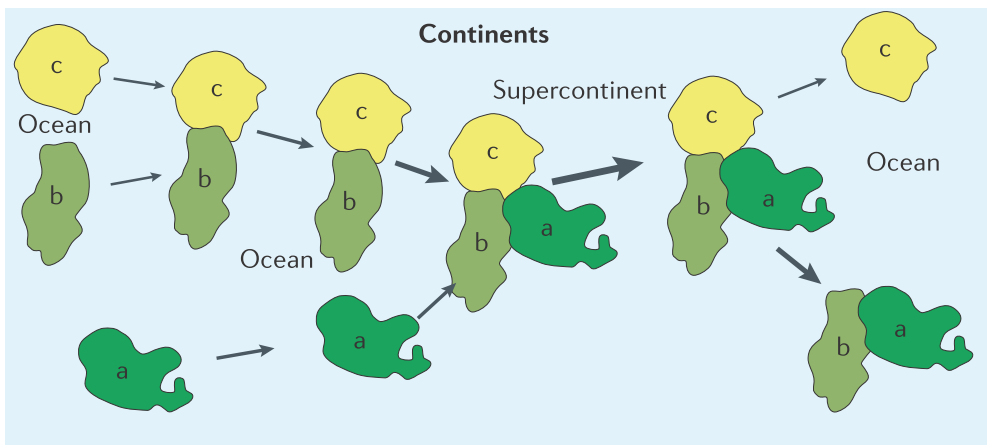

Apparent polar wander paths

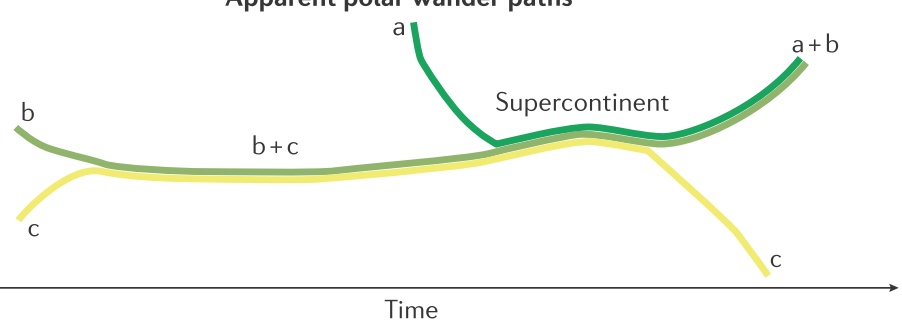


Box 2

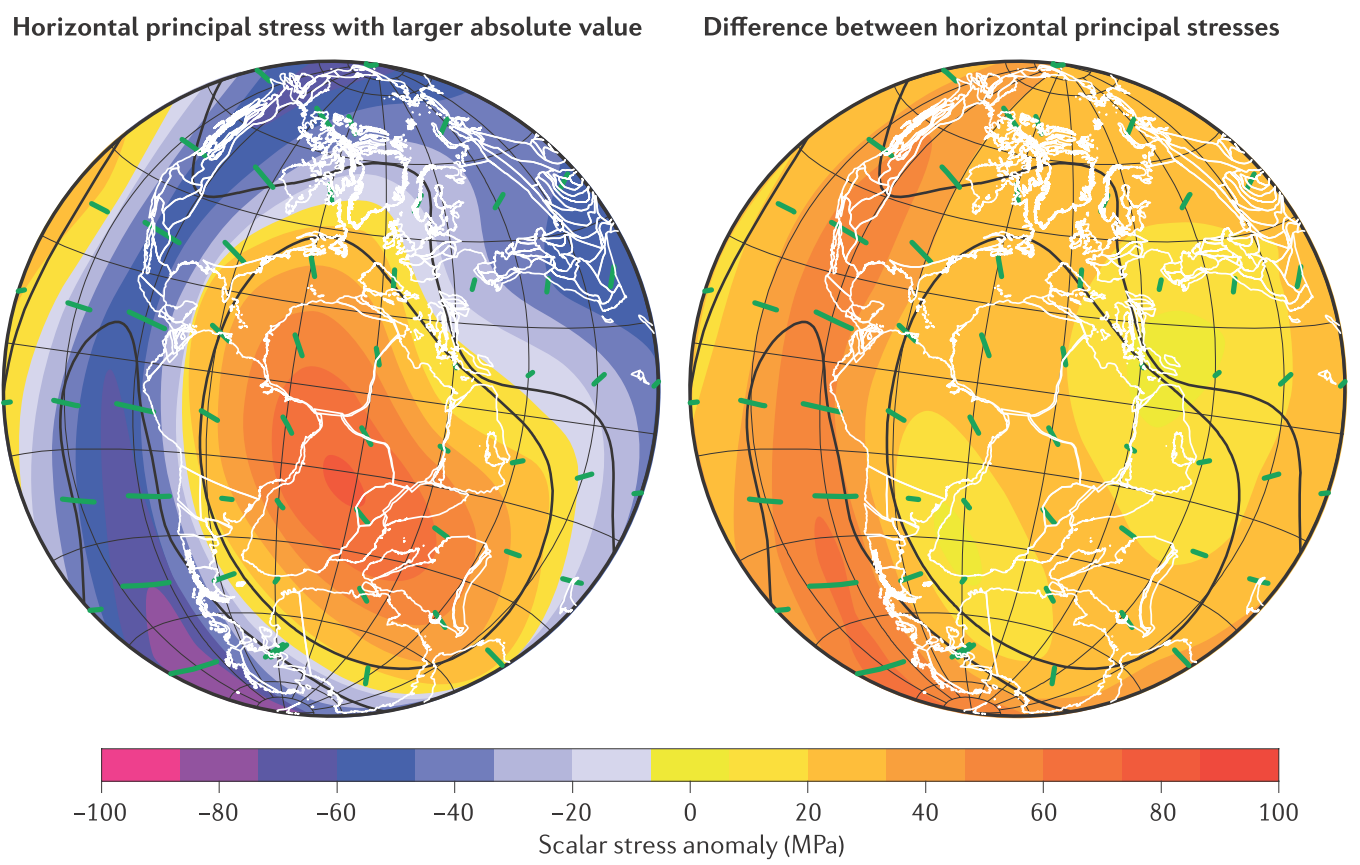

Box 3
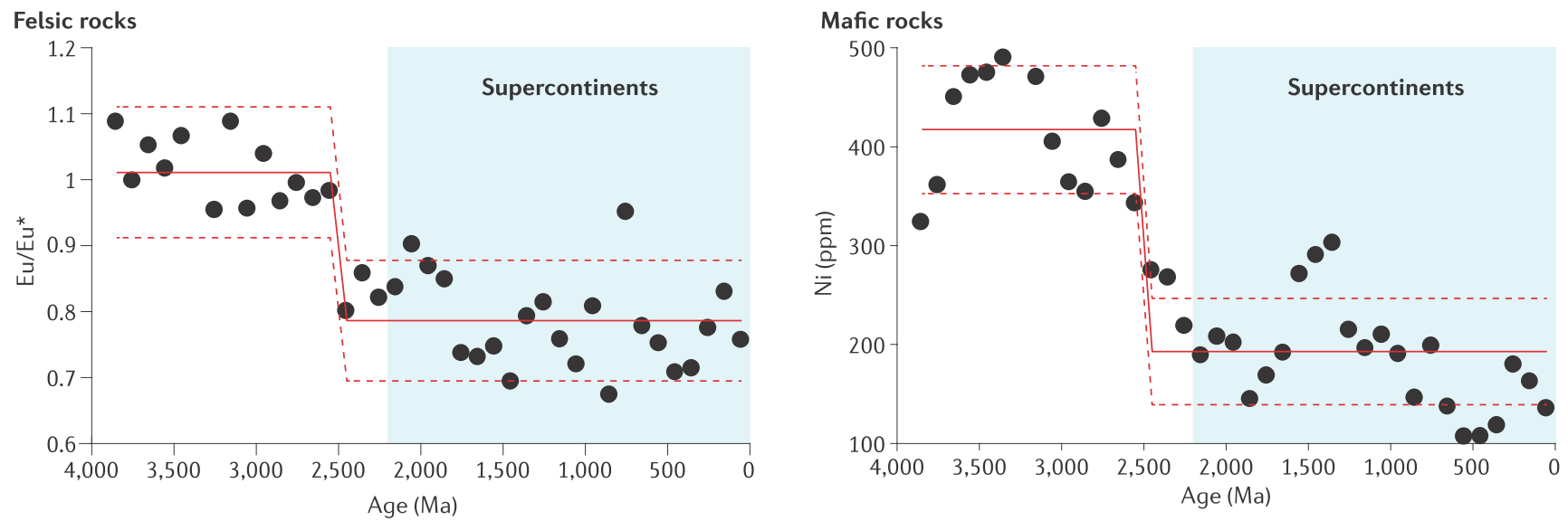